\title{
The Pliocene Ixtacamaxtitlán low sulfidation epithermal deposit (Puebla, Mexico): A case of fossil fungi consortia in a steam-heated environment
}

\author{
El depósito epitermal de baja sulfuración pliocénico Ixtacamaxtitlán (Puebla, Mexico): Un caso \\ de consorcio de hongos fósil en un ambiente de aguas calentadas por vapor
}

\author{
Antoni Camprubí1 ${ }^{1, *}$, Edith Fuentes-Guzmán ${ }^{1,2,3}$, Pilar Ortega-Larrocea ${ }^{1}$, María Colín-García ${ }^{1}$, \\ Janet Gabites ${ }^{4}$, Luis F. Auqué ${ }^{5}$, Vanessa Colás ${ }^{1}$, Eduardo González-Partida ${ }^{6}$
}

\begin{abstract}
Instituto de Geología, Universidad Nacional Autónoma de México. Ciudad Universitaria, 04510 Coyoacán, CDMX, Mexico.

${ }^{2}$ Laboratorio Nacional de Geoquímica y Mineralogía (LANGEM). Ciudad Universitaria, 04510 Coyoacán, CDMX, Mexico.

${ }^{3}$ Programa de Posgrado en Ciencias de la Tierra, Universidad Nacional Autónoma de México. Ciudad Universitaria, 04510 Coyoacán, CDMX / Boulevard Juriquilla 3001, 76230 Juriquilla, Querétaro, Mexico.

${ }^{4}$ Pacific Centre for Isotopic and Geochemical Research, Department of Earth, Ocean and Atmospheric Sciences, University of British Columbia; Earth Sciences Building, 2207 Main Mall, Vancouver, British Columbia, V6T 1Z4, Canada.
\end{abstract}

${ }^{5}$ Departamento de Ciencias de la Tierra, Universidad de Zaragoza. C/ Pedro Cerbuna 12, 50009 Zaragoza, Spain

${ }^{6}$ Centro de Geociencias, Universidad Nacional Autónoma de México. Boulevard Juriquilla 3001, 76230 Juriquilla, Querétaro, Mexico.

* Corresponding author: (A. Camprubí) camprubi@comunidad.unam.mx

How to cite this article:

Camprubí, A., Fuentes-Guzmán, E., OrtegaLarrocea, P., Colín-García, M., Gabites, J., Auqué, L.F., Colás, V., González-Partida, E., 2020, The Pliocene Ixtacamaxtitlán low sulfidation epithermal deposit(Puebla, Mexico): A case of fossil fungi consortia in a steam-heated environment: Boletín de la Sociedad Geológica Mexicana, 72 (3), A140420. http://dx.doi. org/10.18268/BSGM2020v72n3al 140420

Manuscript received: November 4, 2019

Corrected manuscript received: April 1, 2020

Manuscript accepted: April 14, 2020

Peer Reviewing under the responsibility of Universidad Nacional Autónoma de México.

This is an open access article under the CC B1-NC-SA license(https://creativecommons.org/licenses/by-nc-sa/4.0/)

\section{ABSTRACT}

The Ixtacamaxtitlán area in northern Puebla (central Mexico) contains middle Miocene $\mathrm{Cu}-\mathrm{Mo}-\mathrm{Au}$ porphyry/skarn and Pliocene low-sulfidation $\mathrm{Au}-\mathrm{Ag}$ epithermal deposits that are geologically associated with the evolution of the Trans-Mexican Volcanic Belt (TMVB). In this paper, a new ${ }^{40} \mathrm{Ar} /{ }^{39} \mathrm{Ar}$ age $(2.87 \pm 0.41 \mathrm{Ma})$ is provided for rhombohedral alunite from a kaolinite + alunite \pm opal \pm cristobalite \pm smectite advanced argillic alteration assemblage. This age contributes to the definition of a metallogenic province that is confined to the TMVB, a relevant feature for regional exploration. A $\sim 12 \mathrm{My}$ gap is established between the formation of the Cu-Mo-Au porphyry/ skarn and low-sulfidation Au-Ag epithermal deposits, which rules out the possibility that their overlapping was the result of telescoping. Advanced argillic alteration is conspicuous throughout the mineralized area. This alteration assemblage consists of a widespread kaolinite-rich blanket that underlies silica sinters, polymictic hydrothermal breccias, and an alunite-rich spongy layer that consists of vertical tubular structures that are interpreted as the result of gas venting in a subaerial environment. The above indicate a shallow hypogene origin for the advanced argillic alteration assemblage - that is, formation by the partial condensation within a phreatic paleoaquifer of acidic vapors that were boiled-off along fractures that host epithermal veins at

\section{RESUMEN}

El área de Ixtacamaxtitlán en el norte de Puebla (México central) contiene depósitos de tipo pórfido/skarn de Cu-Mo-Au del Mioceno medio y depósitos epitermales de baja sulfuración de Au-Ag del Plioceno, que están geológicamente asociados a la evolución de la Faja Volcánica Trans-Mexicana (FVTM). En este trabajo se presenta una nueva edad ${ }^{40} \mathrm{Ar} /{ }^{39} \mathrm{Ar}$ (2.87 \pm $0.41 \mathrm{Ma}$ ) en alunita romboédrica procedente de una asociación de alteración argílica avanzada constituida por kaolinita + alunita \pm ópalo \pm cristobalita \pm esmectita. Esta edad contribuye a la definición de una provincia metalogenética circunscrita a la FVTM, lo cual constituye un rasgo relevante para la exploración regional. Se ha determinado un lapso de $\sim 12$ millones de años entre la formación de los depósitos de tipo pórfido/skarn de Cu-Mo-Au y los depósitos epitermales de baja sulfuración de Au-Ag, lo cual invalida la posibilidad de que la superposición existente entre dichos depósitos constituya un auténtico telescopaje, contrariamente a interpretaciones previas. Además, dentro de dicho lapso se produjo la formación de un estratovolcán en el área de estudio, que habría interferido en cualquier actividad hidrotermal existente. La asociación de alteración argílica avanzada es reconocible en un área extensa de la zona mineralizada. Dicha asociación consiste en un amplio cuerpo subhorizontal rico en kaolinita que subyace a sinteres silícicos, brechas hidrotermales polimicticas, y un horzonte de aspecto esponjoso rico en alunita que consiste en estructuras verticales tubulares que se interpretan en este trabajo como debidas al escape de gases en un ambiente subaéreo. Tales características son compatibles con un ambiente de formación hipogénico somero para la asociación de alteración argílica avanzada - esto es, formación en terrenos calentados por vapor derivados de la condensación parcial en un paleoacuifero freático de vapores ácidos gene- 
depth. The formation of the spongy alunite layer and silica sinters is interpreted to have been synchronous.

Within the alunite-rich spongy layer, tubular structures hosted microbial consortia dominated by fungi and possible prokaryote (Bacteria or Archaea) biofilms. Such consortia were developed on previously formed alunite and kaolinite and were preserved due to their replacement by opal, kaolinite, or alunite. This means that the proliferation of fungi and prokaryotes occurred during a lull in acidic gas venting during which other organisms (i.e., algae) might have also prospered. Periodic acidic gas venting is compatible with a multi-stage hydrothermal system with several boiling episodes, a feature typical of active geothermal systems and of low-sulfidation epithermal deposits. The microstructures, typical for fungi, are mycelia, hyphae with septa, anastomoses between branches, and cord-like groupings of hyphae. Possible evidence for skeletal remains of prokaryote biofilms is constituted by cobweb-like microstructures composed of $<1 \mu \mathrm{m}$ thick interwoven filaments in close association with hyphae (about $2.5 \mu \mathrm{m}$ thick). Bioweathering of previously precipitated minerals is shown by penetrative biobrecciation due to extensive dissolution of kaolinite by mycelia and by dissolution grooves from hyphae on alunite surfaces. Such bioweathering was possibly predated by inorganically driven partial dissolution of alunite, which suggests a lull in acidic gas venting that allowed living organisms to thrive. This interpretation is sustained by the occurrence of geometrical dissolution pits in alunite covered by hyphae. Fungal bioweathering is particularly aggressive on kaolinite due to its relatively poor nutrient potential. Such delicate microstructures are not commonly preserved in the geological record. In addition, numerous chalcopyrite microcrystals or microaggregates are found within the alunite layer, which could be related to sulfate reduction due to bacterial activity from the sulfate previously released by fungal bioweathering of alunite. Hydrogeochemical modeling constrains $\mathrm{pH}$ to between $\sim 3.2$ and $\sim 3.6$ and temperature to between 53 and $75^{\circ} \mathrm{C}$ during the stage in which fungi and other organisms thrived. These waters were cooler and more alkaline than in earlier and later stages, which were characterized dominantly by steam-heated waters. The most likely process to account for this interlude would be mixing with meteoric water or with upwelling mature water that did not undergo boiling.

Keywords: ${ }^{40} \mathrm{Ar} /{ }^{39} \mathrm{Ar}$ dating, alunite, advanced argillic alteration, steam-heated grounds, fungi, bacteria, bioweathering, biomineralization, TransMexican Volcanic Belt. rados por ebullición a lo largo de fracturas que eventualmente alojaron vetas epitermales en profundidad. Se interpreta que la formación del horizonte esponjoso de alunita y de los sínteres silícicos fue sincrónica.

En el interior de las estructuras tubulares de alunita se desarrollaron consorcios dominados por hongos que también incluyen posibles biofilmes de procariontes (bacterias o arqueas). Dichos consorcios se desarrollaron sobre alunita y kaolinita previamente precipitadas, y fueron preservados debido a su reemplazamiento por ópalo, kaolinita o alunita. Ello conlleva que la proliferación de hongos y procariontes se produjo en periodos de pausa en la emanación de gases ácidos, durante los cuales otros organismos (i.e., algas) pudieron haber igualmente prosperado. Este rasgo es compatible con un sistema hidrotermal multiepisódico con diversas etapas con ebullición, lo cual concuerda con el ambiente de formación de los depósitos epitermales de baja sulfuración. Las microestructuras observadas típicas de hongos son micelios, hifas septadas, anastomosis entre ramificaciones, y agrupaciones de hifas en forma de cable o cordón. La posible evidencia de restos esqueléticos de biofilmes de procariontes la constituyen microestructuras semejantes a telarañas formadas por el entramado de filamentos con grosores $<1 \mu \mathrm{m}$, que se encuentran intimamente asociadas a hifas (éstas, con grosores del orden de $\sim 2.5 \mu \mathrm{m}$ ). La biometeorización de minerales previamente precipitados se muestra en forma de biobrechificación penetrativa debida a la extensa disolución de kaolinita generada por micelios y por el desarrollo de surcos de disolución generados por hifas en la superficie de los cristales de alunita. Dicha biometeorización vino antecedida por la disolución parcial de la alunita, posiblemente de origen inorgánico, lo cual denota la instalación de un ambiente más benéfico (menos ácido) para el desarrollo de organismos vivos y, por tanto, de un periodo de pausa en la exhalación de gases. Dicha interpretación se argumenta con la presencia de mellas geométricas de disolución en alunita, cubiertas por hifas. La biometeorización fúngica es particularmente agresiva en kaolinita debido a su relativamente pobre potencial nutritivo. Estos tipos de microestructuras delicadas no se preservan habitualmente en el registro geológico. Asimismo, se encuentran numerosos microcristales y microagregados de calcopirita en el horizonte de alunita, que pueden ser hipotéticamente asociados a reducción de sulfatos debida a actividad bacteriana, a partir del sulfato previamente liberado por medio de la biometeorización de alunita. El modelado hidrogeoquímico permitió constreñir el pH entre $\sim 3.2$ $y \sim 3.6$ y la temperatura entre $53^{\circ}$ and $75^{\circ} \mathrm{C}$ durante el estadio en que los hongos y otros organismos prosperaron en asociación con aguas más frías y alcalinas que en los estadios precedente y posterior, que se caracterizaron por la presencia dominante de aguas calentadas por vapor. Tales variaciones en temperatura y $\mathrm{pH}$ con respecto a los fluidos precedentes pudieron haber sido consecuencia de la mezcla entre éstos y otros fluidos de nueva incorporación. Los candidatos más verosímiles para permitir dicho interludio serían el agua meteórica o agua ascendente madura que no experimentó ebullición.

Palabras clave: fechamiento ${ }^{40} \mathrm{Ar} /{ }^{39} \mathrm{Ar}$, alunita, alteración argílica avanzada, terrenos calentados por vapor, hongos, bacterias, bioalteración, biomineralización, Faja Volcánica Trans-Mexicana. 


\section{Introduction}

Recent assessment has shown that the metallogenic potential of the mid-Miocene to Holocene Trans-Mexican Volcanic Belt (TMVB) and the potential of Miocene to Holocene ore deposits in Mexico are greater than previously believed (Camprubí, 2009, 2013; Clark and Fitch, 2009; Poliquin, 2009; Jansen et al., 2017; Camprubí et al., 2019; Fuentes-Guzmán et al., 2020a, 2020b). Further, Poliquin (2009) suggested a new epithermal belt that spans such a range of ages, which is geologically associated with the magmatism of the TMVB, and groups the Caballo Blanco, Caldera, San Diego, Picacho, and Ixtacamaxtitlán-Tuligtic deposits. The metallogeny of Miocene to Recent epochs in Mexico is distributed across several regions, namely (1) the southernmost part of the Sierra Madre Occidental in association with its last flare-up, (2) the Trans-Mexican Volcanic Belt (TMVB), (3) the southern part of the Eastern Mexico Alkaline Province (EMAP) and northern Chiapas, (4) the easternmost part of the Sierra Madre del Sur (in Oaxaca), and (5) the Gulf of California. These regional features remain ill defined and require further attention as subjects for future research.

The Ixtacamaxtitlán mineralized area is located in the eastern end of the TMVB, north of Puebla state, and comprises skarn, porphyry $\mathrm{Cu}-\mathrm{Mo}-\mathrm{Au}$, and $\mathrm{Au}-\mathrm{Ag}$ low-sulfidation epithermal deposits (Morales-Ramírez et al., 2003; Tritlla et al., 2004; Poliquin, 2009). Among other features that are typical in the superficial to shallow portions of low-sulfidation epithermal deposits (e.g., Sillitoe, 1993, 2015; Camprubí and Albinson, 2006, 2007; Hamilton et al., 2019), the Ixtacamaxtitlán deposits show (1) banded crustiform veins that contain adularia and bladed calcite, (2) several patches of silica sinters, (3) opal veinlets that fed the sinter, (4) a densely silicified breccia that underlies the veinlets, and (5) a prominent kaolinite + alunite + silica alteration blanket underneath, which constitutes an advanced argillic alteration assemblage that is suggestive of a steam-heated environment (MoralesRamírez et al., 2003; Tritlla et al., 2004; Poliquin, 2009). Similar characteristics were described for the Caldera prospect nearby, in which hydrothermal alunite was dated at $8.3 \pm 0.1 \mathrm{Ma}$ (Poliquin, 2009). Feeder opal veinlets to the sinters above and low-temperature advanced argillic alteration were directly developed on porphyry-type features such as potassic alteration assemblages and relatively high temperature stockworks. In other words, relatively deep porphyry $\mathrm{Cu}-\mathrm{Mo}-\mathrm{Au}$ and skarn deposits at Ixtacamaxtitlán are visibly overlapped by shallow epithermal manifestations. This overlapping led Tritlla et al. (2004) to suggest that the ensemble poses a case for telescoping.

This paper adds up to the geochronological characterization of the ensemble of hydrothermal deposits of Ixtacamaxtitlán, as previous studies focused on the porphyry-type mineralization (Tritlla et al., 2004; Poliquin, 2009) and the overlapping hypogene alteration assemblage around low-sulfidation epithermal veins (Poliquin, 2009). In this study, a shallow hypogene advanced argillic assemblage (alunite + kaolinite + silica) is dated. Further, we provide a detailed analysis of the microstructural features within the assemblage, along with a hydrogeochemical model that constrains the temperature and $\mathrm{pH}$ conditions at which fungi and other organisms thrived. In addition, this paper contributes to a long-standing program that characterizes the geochronology of Mexican mineral deposits and the geologic events with which they are associated in time, space, and genesis (Camprubí et al., 2003, 2015, 2016a, 2016b, 2017a,2017b, 2018, 2019; Farfán-Panamá et al., 2015; Martínez-Reyes et al., 2015; González-Jiménez et al., 2017a, 2017b; Enríquez et al., 2018; Fuentes-Guzmán et al., 2020a, $2020 \mathrm{~b}$ ) in order to better constrain the metallogenic evolution of Mexico, by using the conceptual framework of Camprubí (2009, 2013, 2017).

\section{Geology}

The oldest rocks in the Ixtacamaxtitlán area are basinal facies of limestones interbedded with minor sandstones and shales of the Upper Tamaulipas and Agua Nueva formations, whose ages range between the late Early Cretaceous and the early 


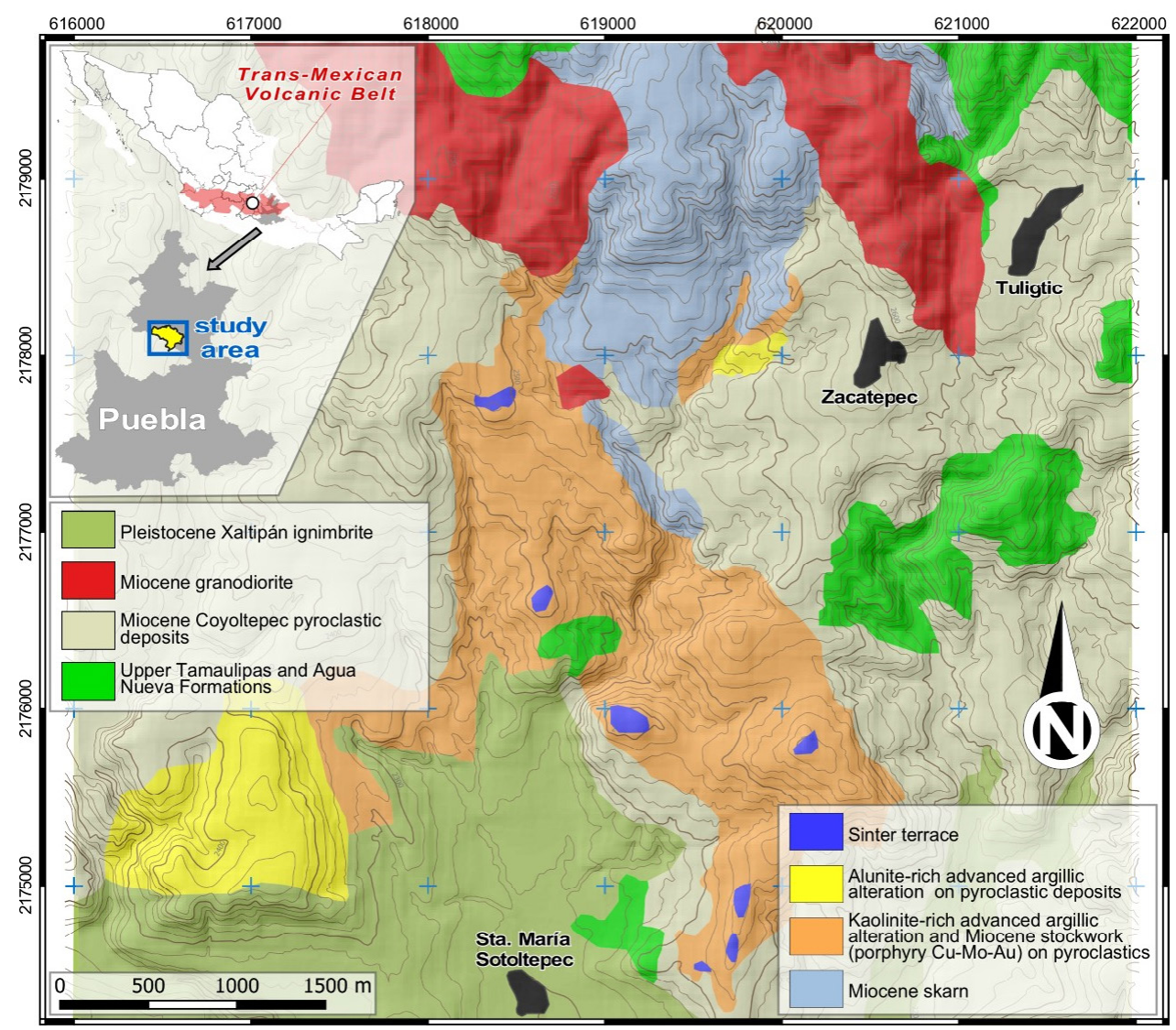

Figure 1 Geological map of the Ixtacamaxtitlán area, northern Puebla (central-south Mexico), modified from Morales-Ramírez (2002).

Late Cretaceous (Figure 1). These rocks correspond geologically to the Sierra Madre Oriental and have been plastically deformed as part of the Mexican Fold and Thrust Belt (Fitz-Díaz et al., 2018). These rocks were unconformably overlain by a Cenozoic volcanic sequence that consists of pyroclastic and ignimbrite deposits. In this area, the Coyoltepec Pyroclastic Deposit consists of a lithic rhyolite tuff composed of massive, strongly polymictic, and lithic-rich pyroclastic flow deposits (Carrasco-Núñez et al., 1997). In this pyroclastic deposit, most of argillic and advanced argillic alteration assemblages in the area were developed due to its pervasiveness, and it also hosts most of the epithermal features, including the mineralized veins. The Xaltipán Ignimbrite consists of rhyolitic ignimbrites with variable welding grades and contains a variety of lithologies as lithic fragments. It was dated at 0.45 土 0.09 Ma (Carrasco-Núñez et al., 1997). Later ash fall deposits covered a still-visible paleosurface, and contain magnetite, apatite, and pyroxenes as heavy minerals (Morales-Ramírez et al., 2003). Hypabyssal diorite, quartz diorite, granodiorite, and tonalite porphyries (Tritlla et al., 2004; Poliquin, 2009) contain associated early Miocene porphyry-type mineralization and locally developed skarns in contact with Cretaceous rocks. These hypabyssal bodies (Figure 1) crosscut both the Cretaceous rocks and the lower part of the Coyoltepec Pyroclastic Deposit (Tritlla et al., 2004), and were dated at $17.7 \pm 0.8 \mathrm{Ma}(\mathrm{U}-\mathrm{Pb}$, zircon; Poliquin, 2009). Porphyry $\mathrm{Cu}-\mathrm{Mo}-\mathrm{Au}$ deposits yielded ${ }^{40} \mathrm{Ar} /{ }^{39} \mathrm{Ar}$ ages at $17.83 \pm 0.06 \mathrm{Ma}$ (biotite from the potassic alteration assemblage; Tritlla et al., 2004) and at $17.9 \pm 0.8 \mathrm{Ma}$ ("sericite" from the phyllic alteration assemblage; Poliquin, 2009), and was exhumed and overlapped by low-sulfidation epithermal veins that yielded $\mathrm{a}^{40} \mathrm{Ar} /{ }^{39} \mathrm{Ar}$ age at $4.3 \pm 0.1 \mathrm{Ma}$ (illite from the phyllic alteration assemblage; Poliquin, 2009). For further detail on the geological setting and ore deposits in the study area, see Morales-Ramírez et al. (2003), Tritlla et al. (2004) and Poliquin (2009). 
All the volcanic and hypabyssal rocks and hydrothermal deposits in the area are associated with the Trans-Mexican Volcanic Belt (TMVB). The age distribution of both rocks and hydrothermal deposits suggests that (1) the Coyoltepec Pyroclastic Deposit, hypabyssal rocks, porphyry $\mathrm{Cu}-\mathrm{Mo}-\mathrm{Au}$, and skarn deposits are associated with the first stage of the TMVB volcanism (early Miocene); (2) the epithermal deposits correspond to the bimodal volcanism of the third stage (Pliocene); and (3) the Xaltipán Ignimbrite corresponds to the fourth stage (Quaternary), as of Gómez-Tuena et al. $(2005,2007)$.

\section{Methodology}

\subsection{MINERALOGICAL STUDIES}

The sample inspection was carried out by a Hitachi TM-1000 scanning electron microscope with an energy dispersive spectrometer (SEM-EDS). Further mineralogical determinations were carried out by means of shortwave infrared (SWIR) using a portable LabSpec Pro Spectrophotometer (Analytical Spectral Devices, Inc.). Visible and near-infrared reflectance of samples, for the spectral range between 350 and $2500 \mathrm{~nm}$ (with a sampling interval of $2 \mathrm{~nm}$ and a $0.1 \mathrm{~s}$ single scan), was measured using an internal light source and sensor. The spectral resolution was $3 \mathrm{~nm}$ in the $350-1000$ $\mathrm{nm}$ range and $10 \mathrm{~nm}$ in the $1000-2500 \mathrm{~nm}$ range. The SWIR wavelength region (1300-2500 nm) was used for our determinations in order to attain the necessary sensitivity to $\mathrm{OH}, \mathrm{H}_{2} \mathrm{O}, \mathrm{CO}_{3}, \mathrm{SO}_{4}$, $\mathrm{CH}$, and $\mathrm{NH}_{4}$ bonds (Thompson et al., 1999, 2009). Mineral identification was based on the wavelength of absorption and the shape of spectra by using the available spectral libraries and tables (Spectral International Inc., 1994). Both SEM and SWIR equipment are available at the Instituto de Geofísica of the Universidad Nacional Autónoma de México (UNAM). The images obtained through the petrographic study by means of SEM are shown in Figures 2 and 3.

\subsection{HYDROGEOGHEMICAL MODELING}

The $\mathrm{pH}$ values for the hydrothermal waters can be assessed using the present geothermal waters from the Los Azufres field (Michoacán, Mexico) as an analog for the fossil system. The likelihood of such waters for this use relies on the variety of their geochemical characteristics (particularly in composition and $\mathrm{pH}$ ), origin, and evolution, as they were classified among steam-heated, mature, and peripheral waters (González-Partida et al., 2005). Therefore, a full set of chemical composition of hot spring waters located in and around the Los Azufres geothermal field presented by González-Partida et al. (2005) has been used for this purpose. Water samples have been equilibrated with kaolinite and alunite at temperatures between 25 and $150{ }^{\circ} \mathrm{C}$ using the code PHREEQG v.3 (Parkhurst and Appelo, 2013) and the Lawrence Livermore National Library thermodynamic database. The range of calculated $\mathrm{pH}$ and amorphous silica saturation index (SI) values for each of the samples are shown in Table 1. The $\mathrm{pH}$ ranges thus calculated and represented in Figure 4 for the different types of waters (all of them, in principle, likely to have occurred in the epithermal paleosurfaces of Ixtacamaxtitlán) allowed us to choose the most representative samples for each type. The Cumbres II and Azufres I samples were selected to represent the bimodal behavior of steam-heated waters at the Los Azufres geothermal field. Their representative character was determined upon the most frequent range of calculated $\mathrm{pH}$, as shown in Figure 4. The Zimirao and Casa Lázaro Cárdenas samples were chosen as the geochemically closest representatives of mature and peripheral waters (with respect to a steam-heated water system), respectively. The four selected representative samples were then used to correlate their $\mathrm{pH}$ and temperature in order to obtain likely estimations of the saturation conditions for amorphous silica (opal), in the understanding that alunite and kaolinite were in equilibrium, as shown in Appendix 1 and Figure 5. 

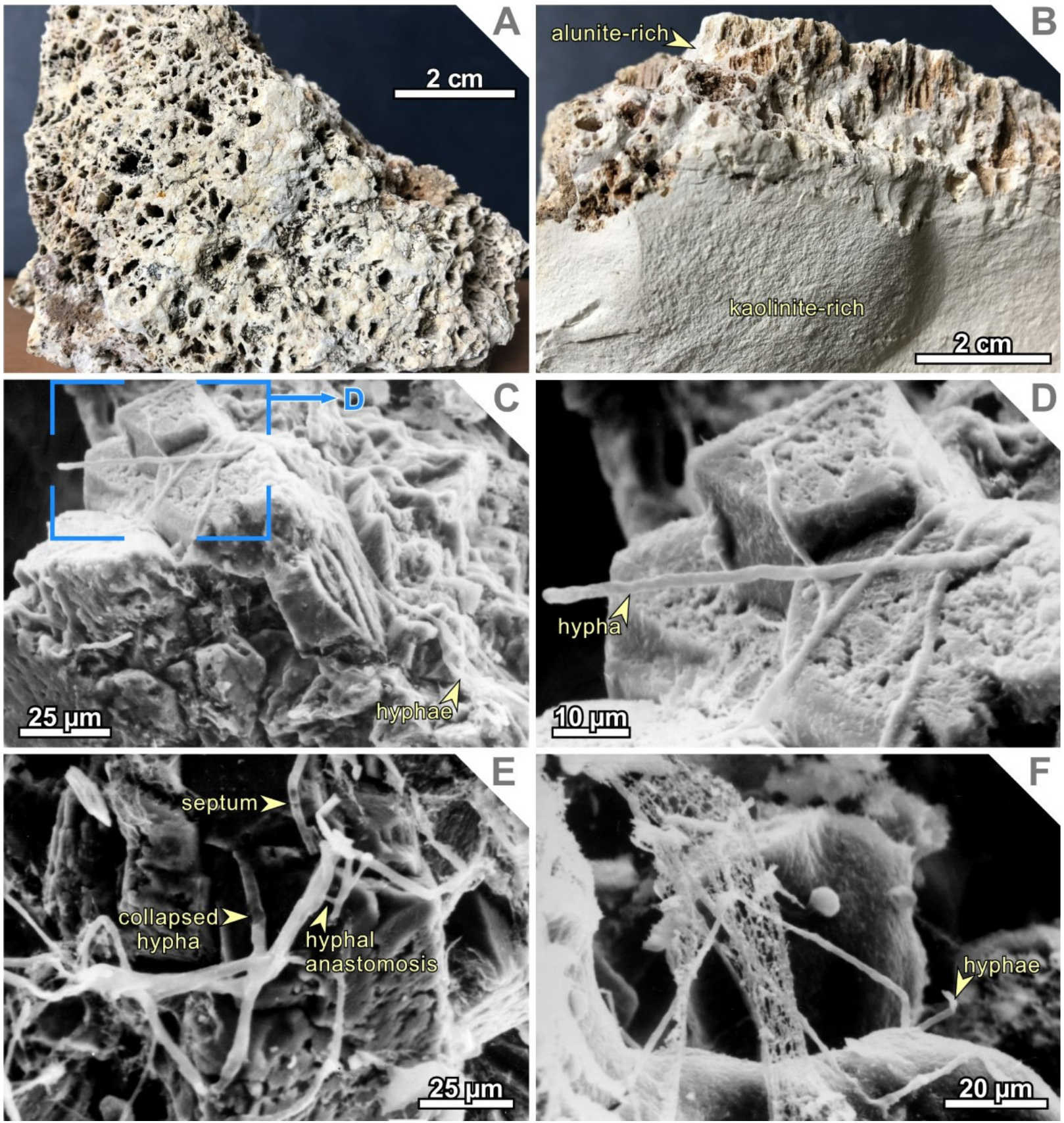

Figure 2 Microstructural, mineralogical, and paleobiological aspects of structures associated with gas venting in advanced argillic associations within a steam-heated ground environment in the Ixtacamaxtitlán epithermal deposits. In all the pictures, fungal hyphae and other possible biological structures are replaced by opal or cristobalite. (A) Upper view of the structures in hand sample showing the high porosity of vents, as tubular cavities, at the paleosurface. (B) Lateral view of (A); notice the columnar arrangement of crystal aggregates (mostly alunite) within each tubular cavity on a relatively low porosity kaolinite + alunite association that includes mm-sized alunite-lined vugs. (C-F) Secondary electron images of the mineralogical and fossil biological content within tubular cavities in (A) and (B). (C) Fungal hyphae attachment parallel to earlier rhombohedral alunite crystals. (D) Close-up image from (C); notice dissolution pits on the surface of alunite crystals where fungal hypha were attached. (E) Hyphae tramlines that show typical structures of fungal networks as septa or anastomosis in septate hyphae for a possible reproduction; as in (D), notice pitted surfaces on alunite crystals due to dissolution. Also notice collapsed hyphae conterminous to bright white, non-collapsed hyphae; this means that collapsed hyphae did not contain cytoplasm because they were already dead before their fossilization whereas non-collapsed hyphae were fossilized while still containing cytoplasm. (F) Fine fungal hyphae spread between opalcovered alunite crystals (hence the smooth surfaces) and on a delicate cobweb-like microstructure that is suggestive of bacteria or archaea biofilms. In all these pictures, fungal hyphae and other possible biological structures are replaced by opal or cristobalite. 

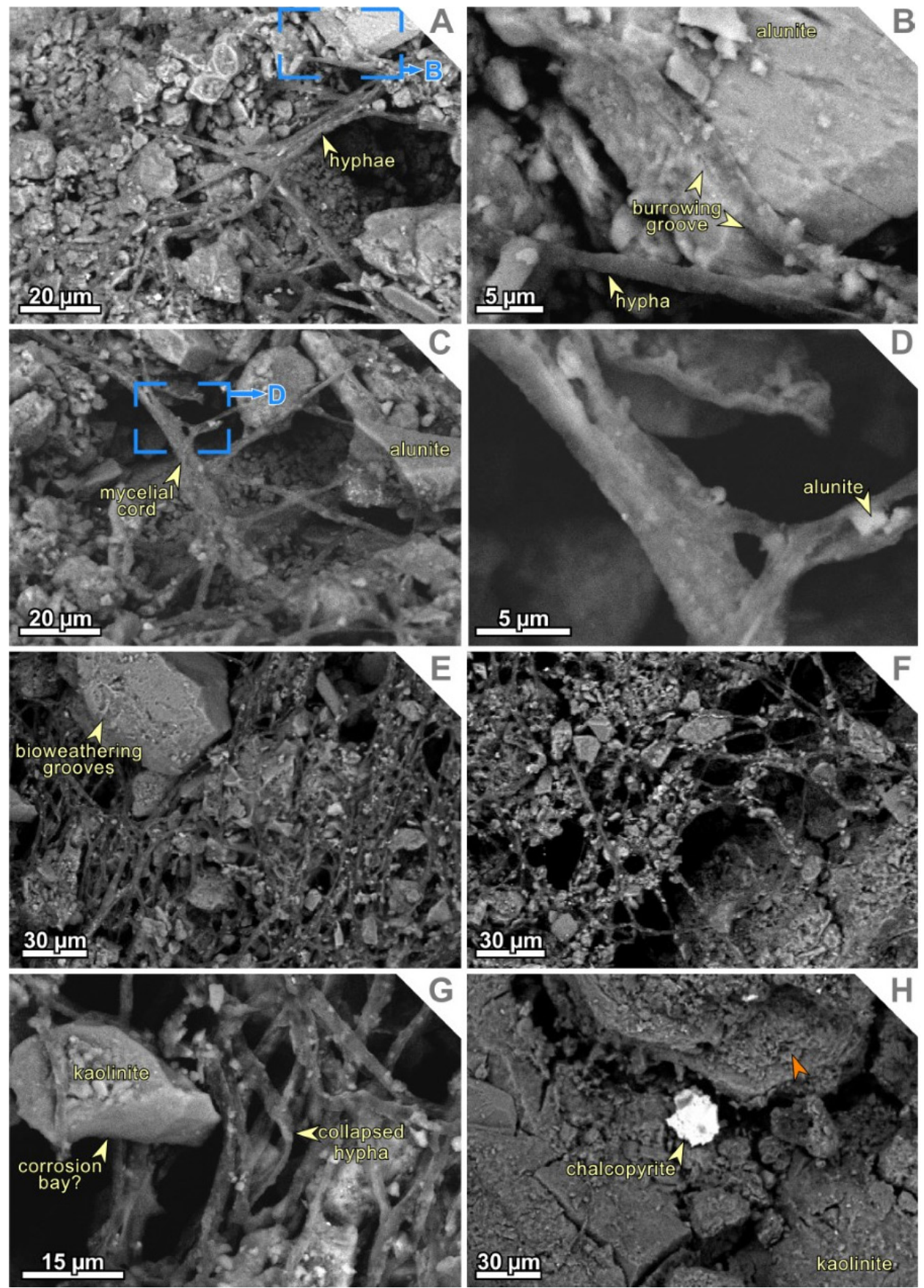

Figure 3 Secondary electron images of microstructural, mineralogical, and paleobiological aspects of structures associated with gas venting in advanced argillic associations within a steam-heated ground environment in the Ixtacamaxtitlán epithermal deposits. In all the pictures, fungal hyphae are replaced by alunite or kaolinite. (A) Basal region of a gas-vent tubular structure where a mesh of fungal hyphae developed among fine and particulate kaolinite and alunite debris. (B) Close-up image of (A) showing surficial concave depressions or grooves on rhombohedral alunite crystals due to hyphae-driven dissolution; notice the good cleavage of alunite on $\{0001\}$, highlighted by dissolution. (C) Mycelial cord structures formed by a parallel assemblage of hyphae; notice curved surfaces developed on alunite crystals due to partial dissolution. (D) Close-up image of the mycelial cord in (C) showing a set of no less than four hyphae and a euhedral alunite microcystal on them, as part of a second generation of alunite. (E, F) Dense networks of interconnected mycelia that show their characteristic particle aggregation (kaolinite fragments due to biobrecciation). (G) Kaolinite aggregate with a corrosion bay adjacent to a mycelial tramline that retains alunite debris (biobrecciation) over superficial hyphae; notice the flattening of some hyphae due to their collapse and see Figure $2 \mathrm{E}$ for an explanation. $(\mathrm{H})$ Chalcopyrite grain on kaolinite; the corrugated surface in the upper part of the picture, signaled with an orange arrowhead, could be due to remains of a fossilized biofilm. In all these pictures, fungal hyphae are replaced by alunite or kaolinite. 
Table 1. Calculated pH and silica saturation index ranges for the geothermal waters from the Los Azufres geothermal field (Michoacán, Mexico) in equilibrium with kaolinite and alunite at temperatures between $25^{\circ}$ and $150{ }^{\circ} \mathrm{C}$, after data from González-Partida et al. (2005).

\begin{tabular}{|c|c|c|c|c|c|}
\hline & Sample & $\begin{array}{l}\text { Measured } \\
\text { temperature }\left({ }^{\circ} \mathrm{C}\right)\end{array}$ & Measured pH & Calculated pH & $\begin{array}{l}\text { Amorphous silica } \\
\text { saturation index }\end{array}$ \\
\hline \multirow{13}{*}{$\begin{array}{l}\text { Steam-heated } \\
\text { waters }\end{array}$} & Agua Fría I & 83 & 6.6 & $3.5-3.9$ & +0.067 to -0.88 \\
\hline & Agua Fría III & 70 & 2.9 & $3.0-3.5$ & +0.47 to -0.44 \\
\hline & Agua Fría IV & 90 & 2.2 & 2.3-2.9 & +0.76 to -0.074 \\
\hline & Azufres I & 29 & 2.5 & $3.2-3.6$ & +0.52 to -0.30 \\
\hline & Cumbres I & 85 & 1.95 & $1.9-2.7$ & +1.057 to -0.50 \\
\hline & Cumbres II & 90 & 2 & $2.1-2.8$ & +0.73 to -0.21 \\
\hline & Currutaco & 50 & 2 & $3.1-3.7$ & +0.91 to -0.10 \\
\hline & Chiflador & 91 & 2.2 & $2.3-2.8$ & +0.82 to -0.034 \\
\hline & Maritaro & 91 & 3.9 & $3.9-3.3$ & +0.58 to -0.31 \\
\hline & Nopalito I & 78 & 2.31 & 2.3-2.9 & +0.67 to -0.33 \\
\hline & Pozo Az-24 & 90 & 7.4 & $3.1-3.5$ & +0.54 to -0.38 \\
\hline & Puentecillas & 63 & 6.64 & $3.5-3.9$ & +0.07 to -0.87 \\
\hline & Tejamaniles II & 68 & 8.3 & $3.4-3.8$ & +0.07 to -0.84 \\
\hline \multirow{3}{*}{ Mature waters } & Laguna Verde & 22 & 2.4 & $2.8-3.1$ & +0.42 to -0.36 \\
\hline & Los Hervideros & 80 & 7.06 & $3.3-3.6$ & +0.03 to -0.82 \\
\hline & Zimirao & 40 & 8 & $3.2-3.5$ & +0.18 to -0.63 \\
\hline \multirow{9}{*}{$\begin{array}{l}\text { Peripheral } \\
\text { waters }\end{array}$} & Casa Lázaro Cárdenas & 44 & 8.4 & $3.6-4.0$ & -0.01 to +0.94 \\
\hline & El Bosque Sta. Rosa & 23 & 8 & $5.5-5.7$ & -2.28 to -2.96 \\
\hline & El Cárcamo & 25 & 6.12 & $5.5-5.7$ & -2.4 to -3.2 \\
\hline & Fabrica La Virgen & 18 & 8.3 & $5.0-5.2$ & -1.86 to -2.6 \\
\hline & Jaripeo & 25 & 8.4 & $6.3-6.7$ & -3.44 to -3.6 \\
\hline & Las Adjuntas & 40 & 6.92 & $4.0-4.4$ & -0.68 to -1.60 \\
\hline & La Herradura & 26 & 8.4 & $5.8-6.1$ & -2.97 to -3.19 \\
\hline & La Trasquila & 20 & 6.92 & $3.6-3.8$ & -0.63 to -1.4 \\
\hline & Santa Rosa I & 18 & 8 & $6.4-6.8$ & -3.58 to -3.70 \\
\hline
\end{tabular}

\section{3. ${ }^{40} \mathrm{Ar} /{ }^{39} \mathrm{Ar}$ DATING}

The alunite samples for geochronological determinations were crushed in a ring mill, washed in distilled water and ethanol, and sieved when dry to $-40+60$ mesh. Appropriate mineral grains were picked out of the bulk fraction. The samples were wrapped in aluminum foil and stacked in an irradiation capsule with similar-aged samples and neutron flux monitors (Fish Canyon Tuff sanidine [FGs], $28.201 \pm 0.046 \mathrm{Ma}$; Kuiper et al., 2008). The samples were irradiated in October 2017 at the McMaster Nuclear Reactor in Hamilton, Ontario, Canada in a shielded can for $6 \mathrm{MWH}$ in the medium flux site 8E. Analyses $(\mathrm{n}=39)$ of 13 neutron flux monitor positions produced errors of $<0.5 \%$ in the $\mathrm{J}$ value. The samples were analyzed at the Noble Gas Laboratory, Pacific Centre for Isotopic and Geochemical Research, University of British Columbia, Vancouver, British Columbia, Canada. The mineral separates were step-heated at incrementally higher powers in the defocused beam of a $10 \mathrm{~W} \mathrm{CO}_{2}$ laser (New Wave Research MIR 10) until fused. The gas evolved from each step was analyzed by a VG5400 mass spectrometer equipped with an ion-counting electron multiplier. All measurements were corrected for total system blank, mass spectrometer sensitivity, mass discrim- 

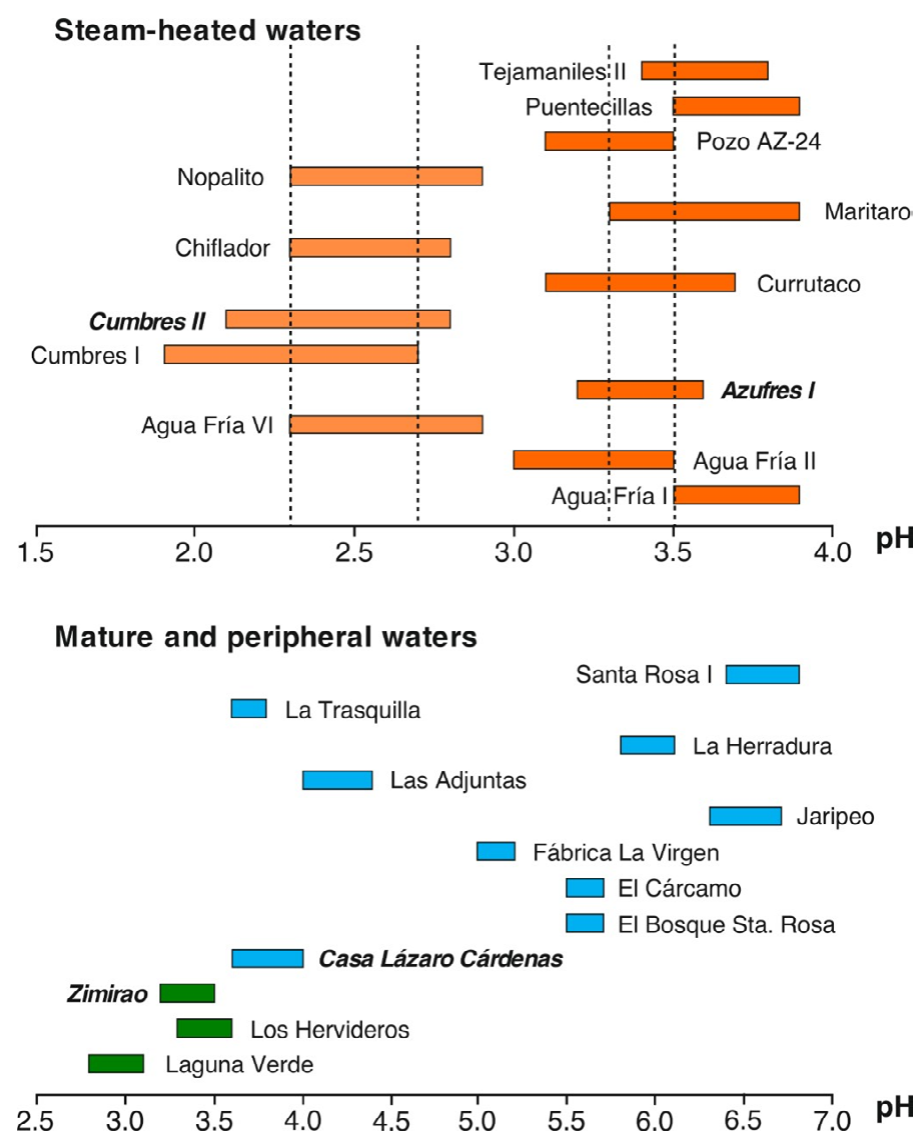

Figure 4 Range of calculated pH for actual steam-heated, mature, and peripheral waters form the Los Azufres geothermal field (Michoacán, Mexico) in equilibrium with kaolinite and alunite. Data on which the modeled waters are based were obtained by González-Partida et al. (2005). These data are used as a reasonable approximation to the environment that prevailed during the formation of the epithermal paleosurfaces in the Ixtacamaxtitlán area. Data derived from hydrogeochemical calculations are displayed in Table 1. Among all samples, those indicated in bold italic typeface were selected for use in Figure 5. Two samples from steam-heated waters were selected as the most representative for the bimodal distribution of $\mathrm{pH}$ data; the most recurrent $\mathrm{pH}$ ranges are indicated with dashed lines. In contrast, two samples from mature and peripheral waters were selected as most representative for the purpose of this study because they do not stray too far from the common range of $\mathrm{pH}$ for acidophile and thermophile fungi (between 3 and 5 ) and their $\mathrm{pH}$ is similar to at least that of another sample.

ination, radioactive decay during and subsequent to irradiation, as well as interfering Ar from atmospheric contamination and the irradiation of $\mathrm{Ca}, \mathrm{Cl}$ and $\mathrm{K}$. The isotope production ratios were: $\left({ }^{40} \mathrm{Ar} /{ }^{39} \mathrm{Ar}\right)_{\mathrm{K}}=0.0005 \pm 0.00006,\left({ }^{37} \mathrm{Ar} /{ }^{39} \mathrm{Ar}\right)$ $\mathrm{Ca}=1048 \pm 0.9,\left({ }^{36} \mathrm{Ar} /{ }^{39} \mathrm{Ar}\right)_{\mathrm{Ca}}=0.3952 \pm 0.0004$, $\mathrm{Ca} / \mathrm{K}=1.83 \pm 0.01\left({ }^{37} \mathrm{Ar}_{\mathrm{Ca}}{ }^{39} \mathrm{Ar}_{\mathrm{K}}\right)$.

Details of the analyses, including plateau (spectrum) and inverse correlation plots, are presented in Table 2 and Figure 6. Initial data entry and calculations were carried out using the software ArArCalc (Koppers, 2002). The plateau and correlation ages were calculated using Isoplot v.3.09 (Ludwig, 2003). Errors are quoted at the 2-sigma (95\% confidence) level and are propagated from all sources except mass spectrometer sensitivity and age of the flux monitor. The best statistically justified plateau and plateau age were picked based on the following criteria: (1) three or more contiguous steps comprising more than $60 \%$ of the ${ }^{39} \mathrm{Ar}$, (2) probability of fit of the weighted mean age greater than $5 \%$, (3) slope of the error-weighted line through the plateau ages equals zero at $5 \%$ confidence, (4) ages of the two outermost steps on a plateau are not significantly different from the weighted-mean plateau age (at $1.8 \sigma$ six or more steps only), and (5) outermost two steps on either side of a plateau must not have nonzero slopes with the same sign (at $1.8 \sigma$ nine or more steps only). 


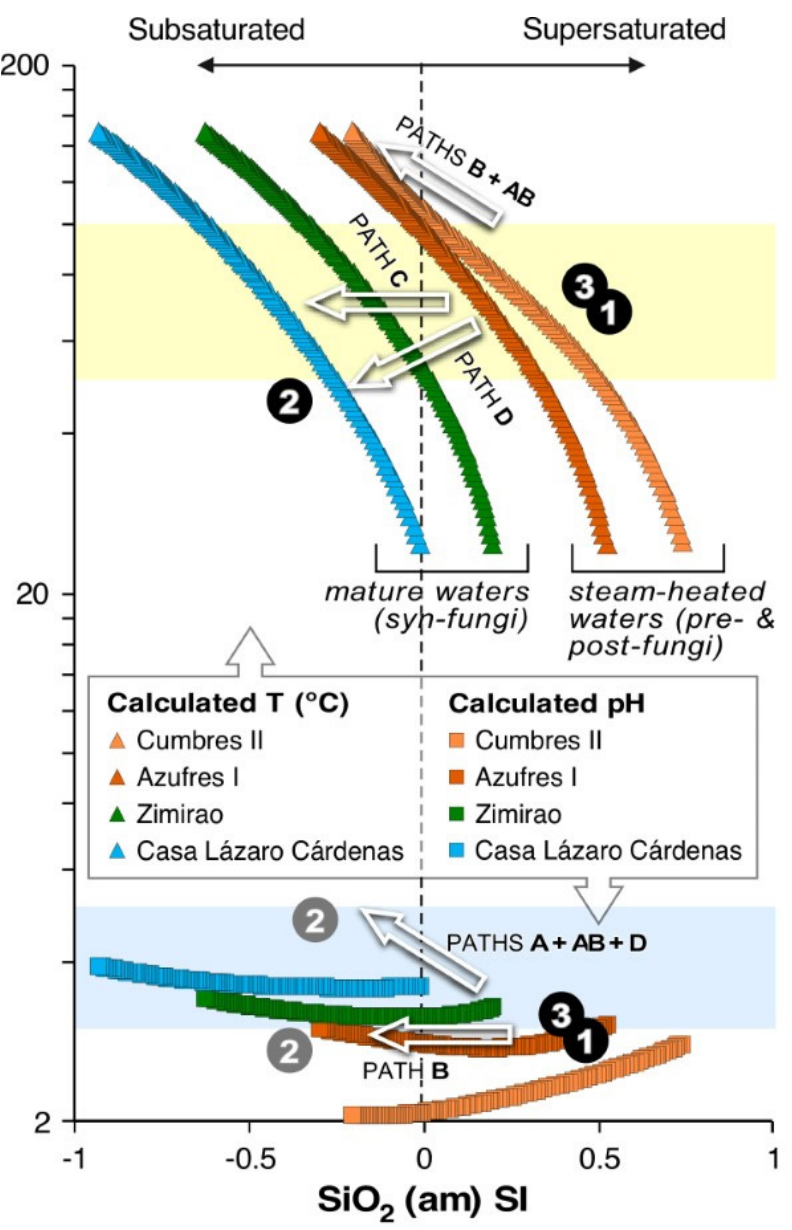

Time sequence:

1 Advanced argillic alteration assemblage (alunite+kaolinite+silica)

2 Decrease in $T$, subsaturation in $\mathrm{SiO}_{2}$, and fungal thriving

3 Reactivation of the steam-heated environment and fossilization of fungi and biofilms

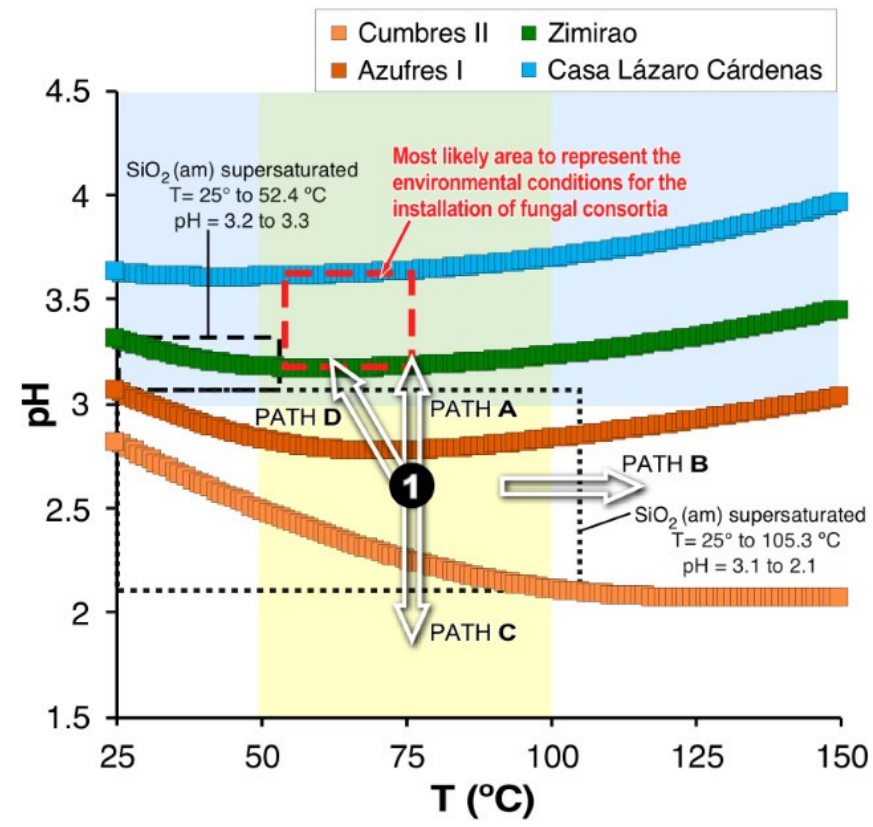

Figure 5 Correlation between the saturation index of amorphous silica $\left[\mathrm{SiO}_{2}(\mathrm{am}) \mathrm{SI}\right]$ and temperature $\left({ }^{\circ} \mathrm{C}\right)$ (upper left), between $\mathrm{SiO}{ }_{2}(\mathrm{am}) \mathrm{SI}$ and $\mathrm{pH}$ (lower left), and between temperature and pH (right), which displays the calculated amorphous silica saturation index for each selected sample in Figure 4. The subsaturation/supersaturation boundaries of amorphous silica are indicated with black dashed lines. The yellow field represents the most reasonable range of temperatures for the installation of fungi in this environment, and the blue shade brackets are the most reasonable range of $\mathrm{pH}$. Numbers 1, 2, and 3 on black circles occupy tentative spaces that are reasonable representatives of the three stages in the steam-heated paleosurface. Number 2 on gray circles represents non-unequivocal possibilities for stage 2 . The possible main paths (A, B, C, D, and AB) for the trajectory between a starting scenario with water supersaturated in amorphous silica into another with water subsaturated in amorphous silica (determined by means of petrographic criteria) are indicated by white empty arrows. Such paths allowed us to constrain the most likely $\mathrm{pH}$-temperature field for water that supported fungal consortia during stage 2 (box dashed in red). As stage 3 represents a return to essentially the same conditions of stage 1 (supersaturation of water in amorphous silica), its position in the $\mathrm{SiO}_{2}(\mathrm{am})$ $\mathrm{SI}$-pH-temperature field is not further addressed.

\section{Results}

\subsection{SAMPLE DESCRIPTION}

Most of the study area is strongly kaolinized and shows partly eroded patches of silica sinter on top (Figure 1; see Morales-Ramírez et al., 2003; Tritlla et al., 2004). The sample examined in this study was collected from a surface exposure within $\sim 10$ $\mathrm{m}$ of one of the remaining patches of silica sinters in the Ixtacamaxtitlán area. Sinter outcrops occur at different heights across the mineralized area, but almost exclusively near the 2400 or $2500 \mathrm{~m}$ contour lines between showings that are $\sim 1000$ $\mathrm{m}$ distant (Figure 1). However, no faults, fractures, or other features that would have significantly disturbed their original position were detected among sinter outcrops. Therefore, it is interpreted that sinter outcrops and patches of alunite-rich layers occur in situ and on a contemporaneous paleosur- 
Table $2 .{ }^{40} \mathrm{Ar} /{ }^{39} \mathrm{Ar}$ step-heating data for the IXT02-6 alunite sample from steam-heated ground-type advanced argillic alteration associated with the low-sulphidation epithermal deposits at Ixtacamaxtitlán, Puebla.

\begin{tabular}{|c|c|c|c|c|c|c|c|c|c|c|c|c|c|c|c|}
\hline Laser & Isotope $\mathrm{R}$ & tios & & & & & & & & & & & & & \\
\hline Power (\%) & ${ }^{40} \mathrm{Ar} /{ }^{39} \mathrm{Ar}$ & $2 \sigma$ & ${ }^{36} \mathrm{Ar} /{ }^{39} \mathrm{Ar}$ & $2 \sigma$ & ${ }^{39} \mathrm{Ar} /{ }^{40} \mathrm{Ar}$ & $2 \sigma$ & ${ }^{36} \mathrm{Ar} /{ }^{40} \mathrm{Ar}$ & $2 \sigma$ & Rho & $\mathrm{K} / \mathrm{Ca}$ & $\%{ }^{40} \mathrm{Ar} \mathrm{rad}$ & $\mathrm{f}^{39} \mathrm{Ar}$ & ${ }^{40} \mathrm{Ar} *{ }^{* 9} \mathrm{ArK}$ & Age & $2 \sigma$ \\
\hline 2.0 & 471.76 & 102 & 1.811 & 0.40 & 0.0021 & 0.0005 & 0.00384 & 0.0002 & 0.02 & 1.39 & 1.35 & 0.04 & 6.350 & 1.81 & \pm 9.59 \\
\hline 2.2 & 766.54 & 13.8 & 3.364 & 0.21 & 0.0013 & 0.0000 & 0.00439 & 0.0003 & 0.01 & 4.68 & -12.78 & 0.98 & 97.95 & -28.20 & \pm 18.1 \\
\hline 2.2 & 2140.78 & 405 & 7.916 & 1.58 & 0.0005 & 0.0001 & 0.00370 & 0.0003 & 0.04 & 5.91 & 4.97 & 0.05 & 106.50 & 30.18 & \pm 47.5 \\
\hline 2.3 & 610.77 & 46.3 & 2.393 & 0.22 & 0.0016 & 0.0001 & 0.00392 & 0.0002 & 0.09 & 4.31 & -0.69 & 0.67 & 4.220 & -1.21 & \pm 13.0 \\
\hline 2.6 & 78.49 & 10.4 & 0.260 & 0.024 & 0.0127 & 0.0017 & 0.00331 & 0.0004 & 0.75 & 5.94 & 15.03 & 8.05 & 11.800 & 3.37 & \pm 2.96 \\
\hline 2.7 & 46.89 & 1.21 & 0.139 & 0.008 & 0.0213 & 0.0005 & 0.00297 & 0.0002 & 0.23 & 6.55 & 23.77 & 46.10 & 11.147 & 3.18 & \pm 0.75 \\
\hline 2.8 & 47.41 & 1.30 & 0.150 & 0.010 & 0.0211 & 0.0006 & 0.00316 & 0.0002 & 0.16 & 5.85 & 18.69 & 32.58 & 8.862 & 2.53 & \pm 0.85 \\
\hline 2.9 & 54.45 & 2.22 & 0.174 & 0.012 & 0.0184 & 0.0007 & 0.00320 & 0.0002 & 0.24 & 8.59 & 17.78 & 4.24 & 9.681 & 2.76 & \pm 1.04 \\
\hline 3.0 & 58.39 & 1.03 & 0.189 & 0.011 & 0.0171 & 0.0003 & 0.00324 & 0.0002 & 0.07 & 10.11 & 16.83 & 5.76 & 9.831 & 2.81 & \pm 0.96 \\
\hline 3.1 & 74.35 & 2.35 & 0.248 & 0.015 & 0.0134 & 0.0004 & 0.00334 & 0.0002 & 0.33 & 6.06 & 14.17 & 1.52 & 10.538 & 3.01 & \pm 1.36 \\
\hline
\end{tabular}

$\mathrm{J}=0.00015610 \pm 0.00000023 ;$ Volume ${ }^{39} \mathrm{ArK}=1.924 \times \mathrm{E}-13 \mathrm{~cm} 3 \mathrm{NPT}$

Integrated Date $=2.86 \pm 0.41 \mathrm{Ma}$

Plateau Age $=2.86 \pm 0.41 \mathrm{Ma} \quad(2 \mathrm{~s}$, including J-error of $.2 \%), \mathrm{MSWD}=1.7$, probability $=0.087,100 \%$ of the ${ }^{39} \mathrm{Ar}$, steps 1 through 10

Inverse isochron (correlation age) results: Model 1 Solution ( $\pm 95 \%$-conf.) on 9 points

Age $=2.79 \pm 0.62 \mathrm{Ma} \quad$ Initial ${ }^{40} \mathrm{Ar} /{ }^{36} \mathrm{Ar}=257.9 \pm 9.7, \mathrm{MSWD}=0.64$, Probability $=0.72$

face. The sample was taken from a $\sim 1 \mathrm{~m}^{2}$ beige to bright white sponge-like subhorizontal patch in which the spongy appearance (Figure 2A) is due to a few $\mathrm{cm}$ long vertical tubular structures (Figure 2B), which are constituted almost entirely of alunite. Additional minor minerals are kaolinite, opal, and, to a lesser extent, chalcopyrite. The walls of the remaining porosity in the tubular structures are essentially covered by a tapestry of euhedral (rhombohedral) alunite crystals (Figure 2C to 2E); those, in turn, can be covered by opal, thus developing smooth surfaces (Figure 2F). Such rhombohedral alunite crystals normally show micron-sized cavities on their surface (Figure 2C to 2E) or other evidence for inorganic dissolution, either favored by the cleavage of alunite or not (Figure 3). Kaolinite constitutes the floor of the tubular structures, and chalcopyrite crystals or aggregates up to a few tens of microns in diameter are common on the floor or the lower portion of the structures (Figure $3 \mathrm{H})$.

A remarkable characteristic of these tubular structures is the occurrence of thread-like microstructures of likely organic origin that have been replaced by opal (Figure 2), alunite, or kaolinite (Figure 3). Most of the organogenic microstructures are compatible with the architecture of fungi (hyphae) whereas some have a dubious origin despite an organic resemblance. The latter are $<1$ $\mu \mathrm{m}$ thick individual filaments interwoven into a cobweb-like microstructure in contact with fungal structures (Figure 2F). Fungal structures are filaments (hyphae) with irregular borders, sometimes bifurcated, about $2.5 \mu \mathrm{m}$ wide with contrasting superficial densities. Some transects look darker and have been flattened, as fossilized empty structures (Figures 2C to 2E and 3G). Such an observation is relevant because it means that part of the mycelium was already dead when fossilization processes occurred. However, each cellular compartment divided by septa allowed fungi to survive in stretches where some cells were dead while others were still alive. Hyphae in this study show compelling evidence for septa (Figure 2E) that divide otherwise cellular content, as well as interconnections (i.e., anastomosis; Figure 2E and 2F). Hyphae grew in three-dimensional networks (Figures 2C to $2 \mathrm{~F}$ and 3 ) where sometimes hyphae aggregated in cord-like structures (Figure 3C to 3D). Some hyphae actually developed boring structures or dissolution grooves on alunite crystals (Figure 3B), which constitutes petrographic evidence that suggests that organic acids segregated by hyphae were capable of dissolving alunite. Besides the replacement of hyphae, mycelial cords, and other fungal structures by alunite, a later crystallization of euhedral (rhombohedral) alunite microcrystals was visibly produced on fungal structures (Figure 

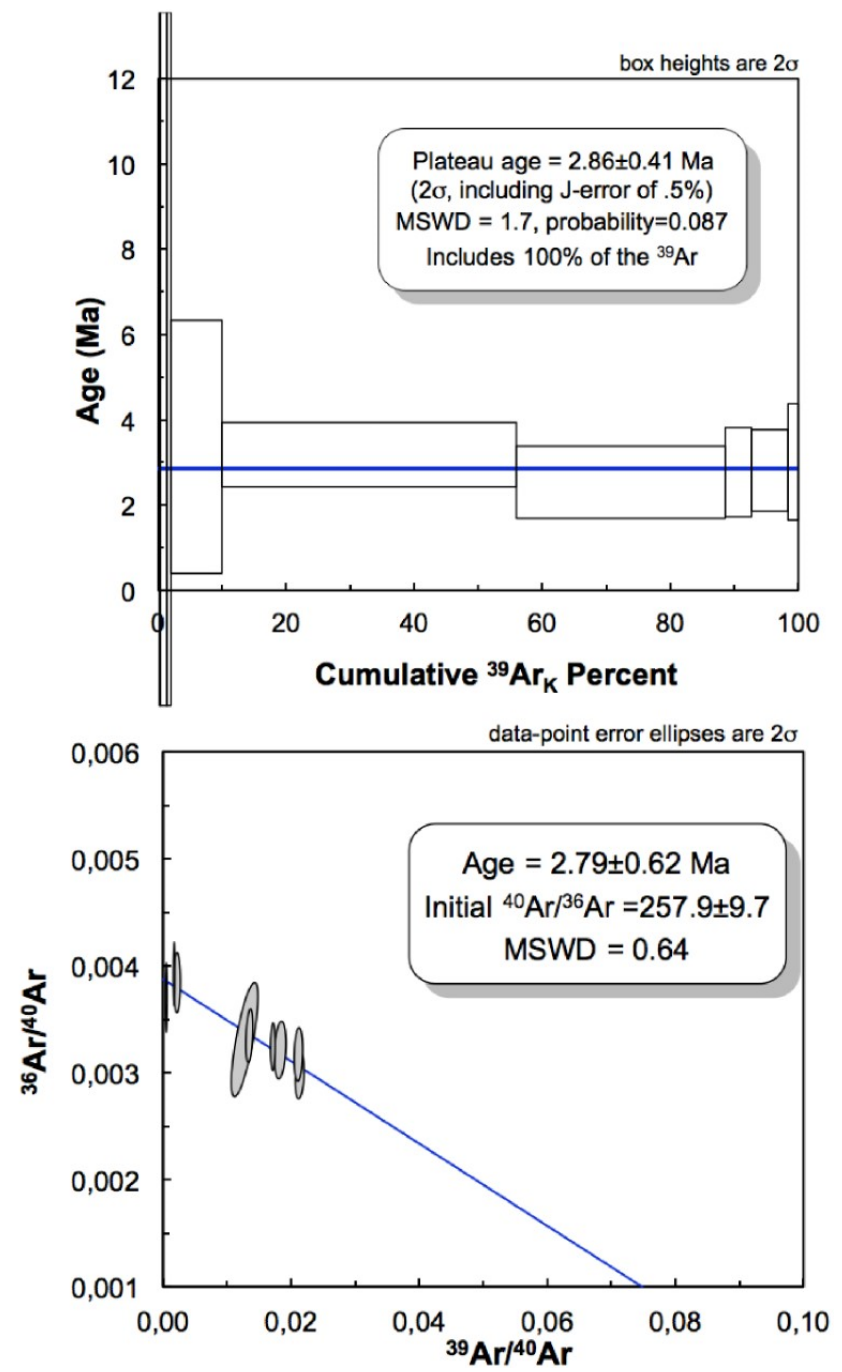

Figure $6 \quad{ }^{40} \mathrm{Ar} /{ }^{39} \mathrm{Ar}$ age spectrum and inverse isochron for an alunite sample from a steam-heated ground-type advanced argillic alteration associated with the low-sulfidation epithermal deposits in the Ixtacamaxtitlán area, Puebla.

$3 \mathrm{~B}$ to $3 \mathrm{D})$. Both replacements and new euhedral alunite stand for, at least, two generations of alunite, thus pointing to a recurrence of the phenomena that gave way to its crystallization, separated by favorable periods for fungi to thrive.

\subsection{GONSTRAINING THE FUNGAL HABITAT THROUGH HYDROGEOCHEMICAL MODELING}

The amorphous $\mathrm{SiO}_{2}$ saturation index $\left(\mathrm{SiO}_{2}(\mathrm{am})\right.$ $\mathrm{SI})$ vs. temperature, amorphous $\mathrm{SiO} 2(\mathrm{am}) \mathrm{SI}$ vs. $\mathrm{pH}$, and temperature vs. $\mathrm{pH}$ diagrams (Figure 5) show the modeled curves for each selected water sample that represent the equilibrium loci for kaolinite and alunite. In other words, these are the curves at which the SI of these minerals equals zero at variable $\mathrm{pH}$, temperature, and amorphous $\mathrm{SiO}_{2}(\mathrm{am}) \mathrm{SI}$. If we accept such water samples from the Los Azufres geothermal field as representative for the different types of water that would be dominant in the Ixtacamaxtitlán area while hydrothermally active, we may characterize the evolution of the dominant fluids in this location in terms of temperature, $\mathrm{pH}$, and $\mathrm{SiO}_{2}(\mathrm{am}) \mathrm{SI}$ through time: (1) steam-heated waters; (2) a lull in the generation of acidic vapors and "invasion" of cooler and more alkaline water (i.e., partly meteoric or mature water) that favored fungal-bacterial consortia; and (3) back to steam-heated waters, and fossilization of fungi and biofilms. This allows us to tentatively position these three stages in the evolution of the advanced argillic alteration assemblages in the Ixtacamaxtitlán mineralized area. During stages 1 and 3, the steam-heated water would be supersaturated in amorphous silica (opal), and thus such water would be located somewhere above the amorphous silica equilibrium (i.e., $\mathrm{SiO}_{2}(\mathrm{am})$ SI $>0$ ). However, during stage 2, opal was redissolved, either inorganically or due to the action of fungi, during the incursion of mature water that can be located somewhere below the amorphous $\mathrm{SiO}_{2}$ equilibrium (i.e., $\mathrm{SiO}_{2}$ (am) $\mathrm{SI}<0$ ). Modeling results (Figure 5) indicate that the stability of the alunite and kaolinite assemblage relies on significant variations in temperature, $\mathrm{pH}$, and saturation conditions for amorphous silica. This means that even slight variations in $\mathrm{pH}$ may easily lead to crossing the amorphous silica supersaturationsubsaturation boundary.

\section{3. ${ }^{40} \mathrm{Ar} /{ }^{39} \mathrm{Ar}$ AGES}

The ${ }^{40} \mathrm{Ar} /{ }^{39} \mathrm{Ar}$ age determined for alunite in the tubular structures is $2.87 \pm 0.41 \mathrm{Ma}$ (integrated age; Figure 6A), which is very similar to the inverse isochron age of $2.79 \pm 0.62 \mathrm{Ma}$ (Figure 6B) and corresponds to the late Pliocene, or Piacenzian. 


\section{Discussion}

\subsection{AGES OF HYDROTHERMAL DEPOSITS}

The ${ }^{40} \mathrm{Ar} /{ }^{39} \mathrm{Ar}$ age yielded by alunite from tubular structures at $2.87 \pm 0.41 \mathrm{Ma}$ corresponds to an advanced argillic alteration assemblage overprint that postdates the deep hypogene epithermal alteration assemblages (dated at $4.3 \pm 0.1 \mathrm{Ma}$; Poliquin, 2009). Nevertheless, this age is still relevant as an indicator of possible contemporaneous, deeper epithermal mineralization (discussed in section 5.2 below). Both ages bracket a minimum range of $\sim 1.3 \mathrm{My}$ for the formation of the low-sulfidation epithermal deposits at Ixtacamaxtitlán in their entirety. Such a range is similar to the general $\sim 1$ to 3 My bracket determined in several intermediate- to low-sulfidation epithermal deposits of different sizes and ages in Mexico (namely, the Pachuca-Real del Monte, Fresnillo, Guanajuato, Zacatecas, Taxco, Tayoltita, and Temascaltepec deposits; Lang et al., 1988; McKee et al., 1992; Camprubí et al., 2003; Camprubí and Albinson, 2007; Velador et al., 2010; Farfán-Panamá et al., 2015; Martínez-Reyes et al., 2015; Enríquez et al., 2018; Zamora-Vega et al., 2018). High-sulfidation epithermal deposits, however, were formed in shorter time spans (Valencia et al., 2005, 2008; Jansen et al., 2017). Therefore, the age difference between the alunite layer and the deep phyllic alteration in the low-sulfidation epithermal mineralization at Ixtacamaxtitlán is not long enough to allow claiming more than one epithermal deposit. On the contrary, such ages are compatible with the existence of different stages of mineralization within the same deposit.

The geological evidence (Carrasco-Núñez et al., 1997; Gómez-Tuena et al., 2000, 2003, 2005, 2007; Morales-Ramirez et al., 2003) and all the available ages of hydrothermal deposits in the Ixtacamaxtitlán area (Figure 7; Tritlla et al., 2004; Poliquin, 2009; and this study) show a tight linkage between the magmatic activity of the Trans-Mexican Volcanic Belt (TMVB) and both the porphyry-type and epithermal deposits. Such ages and those in other articles in this issue (Fuentes-Guzmán et al., 2020a, 2020b) stand collectively for a metallogenesis of the TMVB, as already indicated by Camprubí (2009, 2013) and Poliquin (2009). Specifically, the Cu-Mo-Au porphyry deposits would be associated with the middle to late Miocene arc (first stage of the TMVB, as of Gómez-Tuena et al., 2005, 2007) and the low-sulfidation epithermal deposits would be associated with bimodal volcanism that occurred at the end of the third stage in the evolution of the TMVB.

There is a notorious $\sim 12$ My gap between the available ages for the $\mathrm{Cu}-\mathrm{Mo}-\mathrm{Au}$ porphyry and the low-sulfidation epithermal deposits (Figure 7). Earlier works described the spatial association between the $\mathrm{Cu}-\mathrm{Mo}-\mathrm{Au}$ porphyry/skarn and low-sulfidation epithermal deposits in Ixtacamaxtitlán as a case for telescoping (i.e., as a genetic association; Morales-Ramírez et al., 2003; Tritlla et al., 2004). Despite the clear overlapping in space of these deposits, such a time gap makes it difficult to describe this occurrence as true telescoping (sensu Sillitoe, 2010), as this term implies a progressive thermal decline of the (mineral) systems combined with synmineral paleosurface degradation (that) results in the characteristic overprinting [sic, Sillitoe, 2010]. Such a definition entails a continuum of mineral processes from the deep to the shallow environments, which is necessarily combined with some degree of exhumation that is synchronous to hydrothermal activity. Without the exhumation ingredient, porphyry-type and epithermal environments would be found stacked, not overlapped (therefore, not telescoped; see discussion in Camprubí and Albinson, 2007), although a continuum between both types would still exist. None of these is the case in the Ixtacamaxtitlán deposits. Besides, the nearby Cerro Grande stratovolcano was formed (Figure 7) between the porphyry-type and epithermal deposits (between $\sim 11$ and $9 \mathrm{Ma}$ ). It would have forcefully disrupted hydrothermal activity in the area and, if anything, set the course for a new mineral system on its own (not the case, though). Documented (or claimed) cases for telescoping between porphyry-type or skarn and epithermal 
deposits are not uncommon in the literature (e.g., Simpson et al., 2004; Catchpole et al., 2011; Cooke et al., 2011; Camprubí et al., 2015; Dill et al., 2015; Franchini et al., 2015; Imer et al., 2016; Peng et al., 2017). The present geochronological study demonstrates that overlapping does not necessarily imply telescoping, not even in cases in which the types of deposits involved are likely to be part of the same specific mineral system (sensu Hronsky and Groves, 2008; McGuaig et al, 2010; Hronsky et al., 2012). Therefore, high-resolution geochronological studies remain an essential tool to determine the actual linkage between different types of ore deposits. In the Ixtacamaxtitlán case, Cu-Mo-Au porphyry/skarn and low-sulfidation epithermal deposits are not related in time, and thus it is most unlikely that they are genetically related despite their spatial association. Such an association would then indicate a structural association between these deposits, as it was described, for instance, between volcanogenic massive sulfide and skarn types in the Francisco I. Madero deposit in Zacatecas (Camprubí et al., 2017b). No structural association has been explored for Ixtacamaxtitlán and would make a case for further research - that is, the persistence of structural features through time that would favor the emplacement of ore deposits in the same areas.

\subsection{DEPOSITIONAL ENVIRONMENT OF THE ALUNITE + KAOLINITE ASSOGIATION}

The mineralogy of shallow hydrothermal alteration in the Ixtacamaxtitlán epithermal deposit consists of kaolinite and alunite, with minor quartz, opal, and uncommon and less abundant smectite or illite-smectite. A mineral assemblage vastly dominated by kaolinite and alunite constitutes an advanced argillic alteration assemblage. Such assemblages may occur in any epithermal settings (1) as deep hypogene alteration, that is, in magmatic-hydrothermal environments; (2) as shallow hypogene alteration, that is, in steamheated grounds; or (3) in supergene environments (e.g., Sillitoe, 1993, 2015). The vertical tubular structures found on an in-situ spongy layer are mostly constituted by aggregates of euhedral (rhombohedral) alunite crystals. These structures are very similar to fossil subaerial gas vents (as in Milos island, Greece; https://www.bgs.ac.uk/ research/bufi/photosGallery.html, as of October 2019). These similarities, along with the nature of the fossil remains (discussed in section 5.3 below) within the alunite-rich tubular structures, and the high porosity shown in such structures suggest that their formation was produced in the subaerial part of a steam-heated environment. Both the spongy layer and the hot-spring silica sinters are subhorizontal and subconcordant with the underlying kaolinite + alunite \pm opal \pm smectite alteration envelope (see Morales-Ramírez et al., 2003; Tritlla et al., 2004). In our view, the sinters and the alunite spongy layer would likely have formed simultaneously and thus share the same paleosurface. Therefore, they are interpreted as formed in a steam-heated environment where the spongy layer would be due to acidic gas venting on the paleosurface (i.e., Sillitoe, 2015) peripherally to the silica sinters. Such an environment requires the occurrence of boiling at depth, which is corroborated by the occurrence of adularia in the veins (Poliquin, 2009). Then, boiled-off acidic vapors would have condensed in a shallow paleoaquifer, as demonstrated by the resulting broad subhorizontal kaolinite + alunite \pm opal \pm cristobalite \pm smectite blanket below the hot-spring silica sinters (Figure 1; Morales-Ramírez et al., 2003; Tritlla et al., 2004) that resulted from the pervasive alteration of host rocks by acidic fluids. Evidence for boiling in the epithermal deposits at Ixtacamaxtitlán are the occurrence in mineralized structures of (1) pseudorhombohedral adularia, (2) bladed calcite phantoms (Poliquin, 2009), and (3) coexisting vapor- and liquid-rich fluid inclusions within the same fluid inclusion assemblages in vein minerals (Poliquin, 2009). Eventually, acidic vapors could travel relatively unscathed toward the paleosurface, thus generating the alunite-dominated tubular structures shown in this study (Figure 2A and 2B). However, no chalcedony blanket that landmarks the paleo-phreatic level - a typical 


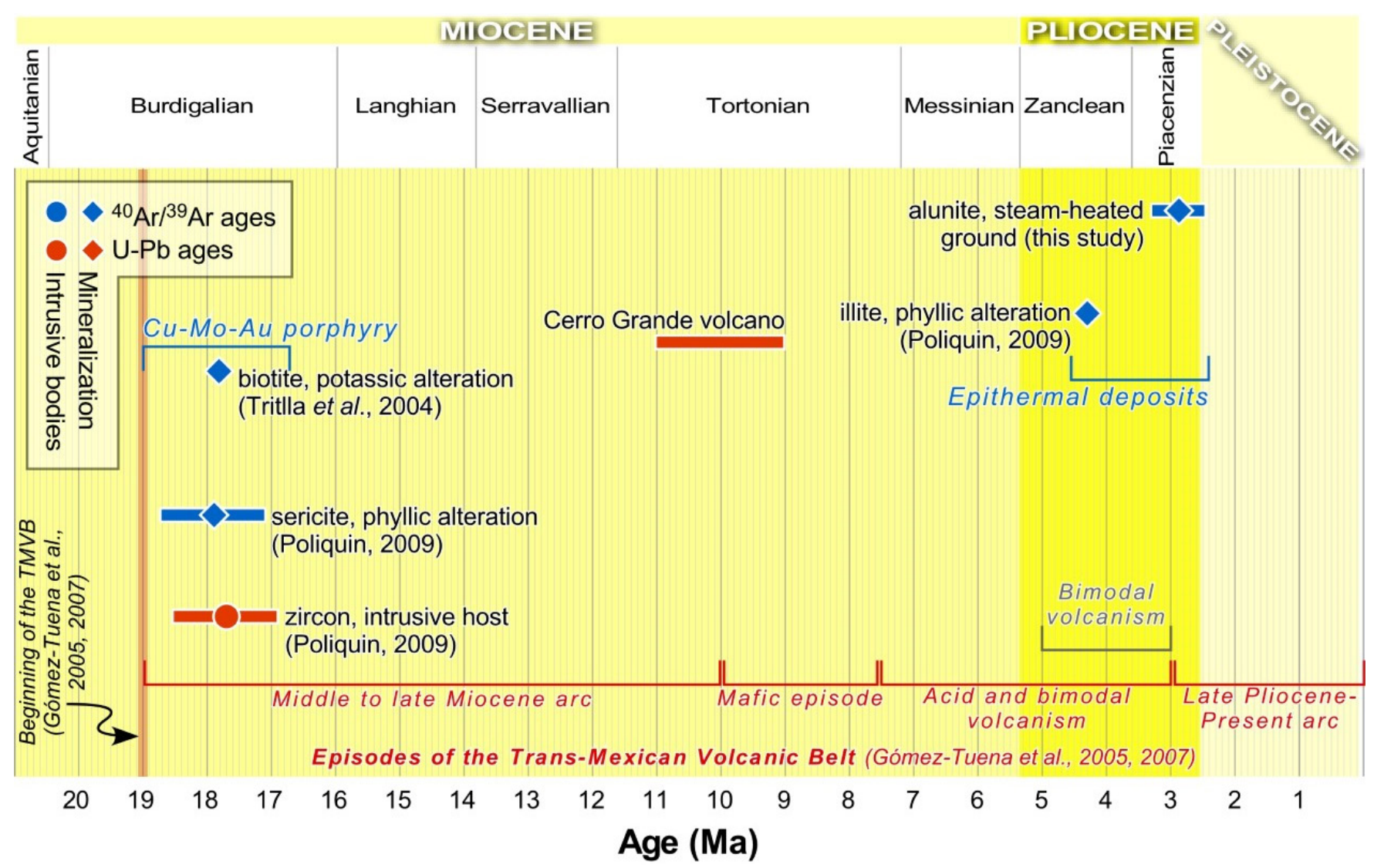

Figure 7 Sequence of magmatic and hydrothermal events in the Ixtacamaxtitlán area since the Miocene with the available ages. The range of ages for the volcanic rocks associated with the Cerro Grande stratovolcano was determined with the data provided by Carrasco-Núñez et al. (1997), Gómez-Tuena and Carrasco-Núñez (2000), and Gómez-Tuena et al. (2003).

feature in this environment (Hedenquist et al., 2000; Sillitoe, 2015) — was found during our surveys in the area.

Such an environment may naturally include periods of quiescence, which are generally favorable for input of water with different temperatures and geochemical characteristics, such as meteoric water or upwelling water from deep sources. The latter may come from different possible sources and evolutionary paths, and thus different geochemical characteristics as well. The modern analog used in this paper for a steam-heated environment is the Los Azufres geothermal field in Michoacán. The reason for such a choice is that González-Partida et al. (2005), among other characteristics that are shared with the epithermal deposits at Ixtacamaxtitlán, provided evidence for the concurrence of (1) boiled-off acidic water; (2) meteoric water; (3) fluids with different degrees of chemical equilibration with host rocks; (4) mixing phenomena between upwelling hydrothermal fluids and meteoric water; (5) prevailing advanced argillic alteration assemblages of the shallow hypogene type; (6) the occurrence of sinters; and (7) some degree of space zonation of the different types of waters, which range from steam-heated to mature and peripheral waters. Therefore, we use that temperature and geochemical data obtained by González-Partida et al. (2005) in our geochemical modeling, as well as a conceptual analog to the subject of study.

\subsection{ROLES OF FUNGI}

In the present study, the fossils of fungal remains are exceptionally well preserved, allowing us to iden- 
tify mycelia, hyphae with septa, and anastomoses between branches, among other characteristically fungal features (Figures 2 and 3). Such remains are fossilized by opal, kaolinite, and alunite at Ixtacamaxtitlán, although fungi have been described to be much less prone to silicification than other organisms (Jones et al., 1999; Konhauser et al., 2004). Silicification of microbes in hot-spring environments would have occurred rapidly, within a few days after their demise and before their soft tissues started to collapse or organic matter started degrading at the temperatures that are typical for these environments (Jones et al., 2004). Although we are unaware of fungi fossilization by kaolinite or alunite in other locations, and silica minerals are the common preservers of fungal remains, fungi by a geyser in Lake Ngakoro in New Zealand were fossilized by both silica and jarosite (Jones et al., 2000) and show strong similarities with the remains described in this paper (compare Figures 2 and 3 in this paper with Figures 7 and 9 in Jones et al., 2000).

Relatively regular-shaped dissolution pits in alunite that were not formed by living organisms (Figure 2C to 2E) probably denote cooling of fluids in this environment once it was starved from boiled-off acidic vapor, as alunite destabilizes at temperatures $<200{ }^{\circ} \mathrm{C}$ and at $\mathrm{pH}>3$ (Hedenquist and Taran, 2013; Acero et al., 2015). Once the temperature was low enough to allow fungi to thrive, their activity led to boring on their substrate, which was mostly a tapestry of alunite crystals. In fact, fungi are very effective at degrading silicates, which is an ability that would account for the notorious corrosion bays developed on kaolinite (Figure $3 \mathrm{E}$ and $3 \mathrm{~F}) ;$ e.g., Aspergillus niger degrades kaolinite and several other silicates (Sterflinger, 2000). In subaerial hydrothermal systems or deposits, fungal evidence can be interpreted in terms of paleoecological changes or as cycles in hydrothermal activity (Figure 8). Provided that fungi are not autotrophic organisms, it can be deduced that the hydrothermal environment would have necessarily had to cool down to allow bacteria or thermophilic archaea to thrive as well, but also algae, which would supply nourishment for fungi. Then, upon the reactivation of hydrothermal activity, new boiling at depth and gas venting in steam-heated grounds would have killed fungi and fossilized them with opal, alunite, or kaolinite (as seen in Figures 2, 3, and 8). The reactivation of acidic-gas venting by subsequent generations of boiled-off vapors is suggested by both the replacement of fungal microstructures by alunite and a second (at least) generation of rhombohedral alunite crystals on fossilized hyphae (Figures 3D and 8). The presence of heterotrophic fungi in extreme nutrient-poor habitats have been attributed to three possible explanations: (1) they are nourished by sediments rich in organic remains, (2) they are nourished by abiotic mineral-fluid reactions, or (3) they are nourished by symbiotic relationships with chemoautotrophic prokaryote biofilms that served as a carbon source for anaerobic fungi under anoxic conditions (Bengtson et al., 2014; Ivarsson et al., 2015, 2016). In this sense, the cobweb-like structure in Figure 2F might represent the fossilized skeletal remains of biofilms (such possibility is further discussed below). All the same, the corrosion bays in kaolinite aggregates (Figure $3 \mathrm{E}$ to $3 \mathrm{G}$ ) and the generally "bio-brecciated" appearance of the mineral-fungal ensemble (Figures 3A, 3F, 3H and 8) are not to be ignored, as they are far more developed than boring on alunite. The intensive dissolution of kaolinite could be explained by the relatively poor nutrient potential of this mineral, which compels the microorganisms that live on kaolinite-rich substrates to be particularly aggressive in order to obtain sufficient metal nutrients (Cuadros, 2017). Fungi are also described to occur on open-air microstromatolitic kaolinite laminae in the Te Whakarewarewatangaoteopetauaawahiao geothermal system in New Zealand (Jones et al., 2001a).

In extreme environments, cavities, cracks, and crevices are suitable sites for fungi development (Ehrlich, 1998; Viles and Gorbushina, 2003; Gorbushina, 2007). Over 80 fungal species have been listed as acidophilic or acid-tolerant (Gross and Robbins, 2000). Although such inventory refers to 
extant species, a $<3$ Ma paleohydrothermal system like the one at Ixtacamaxtitlán may well have harbored similar species, albeit episodically. In fact, fungi (or reasonably suspected to be so) have been found in association with (paleo-)hydrothermal manifestations in the geological record of a broad variety of ages and geological settings (Jones et al., 1999, 2001a, 2001b, 2004; Rasmussen, 2000; Sterflinger, 2000; Fayers and Trewin, 2004; Gadanho and Sampaio, 2005; López-García et al., 2006; Van Dover et al., 2007; Connell et al., 2009; Le Calvez et al., 2009; Chiacchiarini et al., 2010; Ivarsson et al., 2012, 2019; Massini et al., 2012, 2016; Taylor et al., 2015; Dekov et al., 2016; Taksavasu et al., 2018). Such settings include both epithermal and extant geothermal environments.

Another interesting feature in the tubular structures found in Ixtacamaxtitlán is the occurrence of abundant chalcopyrite crystals and aggregates (Figure 3H). The precipitation of sulfides (most noticeably, pyrite) in steam-heated environments is common by inorganic means (Stoffregen et al., 2000; Sillitoe, 2015). However, the occurrence of boring on alunite crystals by hyphae and the subsequent reduction of the released sulfate due to the dissolution of alunite by organic acids could also contribute to the formation of sulfides. Rocks and minerals are indeed altered by fungi (e.g., GómezAlarcón et al., 1994; Hirsch et al., 1995; Sterflinger, 2000). Also, the microbial weathering of rhyolitic obsidian may produce quartz and alunite (Cuadros et al., 2012). Usually, fungi attack minerals by two main mechanisms: by acidification of the environment, and by mechanically disaggregation or aggregation of particles (Sterflinger, 2000). There are two mechanisms of fungal mineralization: (1) controlled, which is mediated by selective exudates depending upon the mineral; and (2) induced, which is mediated by indirect metabolic activity as excreted polymers. Such polymers serve as nucleation sites that promote mineral crystallization, or simply by wall surface charges as adsorption sites that also promote the nucleation of minerals even in dead cells. This mechanism has been demonstrated in jarosite biomineraliza- tion at $\mathrm{pH}$ values $\sim 2$ with acidophillic fungi whose hyphae were completely covered by precipitated jarosite (Oggerin et al., 2013). This case is relevant because jarosite $\left.\left[\mathrm{KFe}_{3}^{3+}{ }_{3} \mathrm{SO}_{4}\right)_{2}(\mathrm{OH})_{6}\right]$ and alunite $\left[\mathrm{KAl}_{3}\left(\mathrm{SO}_{4}\right)_{2}(\mathrm{OH})_{6}\right]$ are isostructural end-members in the alunite supergroup. Further, their stability conditions and geological occurrences can be similar, although jarosite is a rare hypogene mineral because it requires more extreme acidic and oxidizing environments to form (Jones et al., 2000, and references within; Stoffregen et al., 2000). Therefore, relatively slight increases in $\mathrm{pH}$ may result in the dissolution or precipitation of either jarosite or alunite in acidic and oxidizing environments, which makes the behavior of these minerals comparable. Fungi-driven acidification is originated by pumping $\mathrm{H}^{+}$and excreting metabolites like carboxylic acid, among other acids (i.e., oxalic, citric, carbonic, phosphoric, aromatic and aliphatic, etc.; Müller et al., 1995), $\mathrm{CO}_{2}$, siderophores (Renshaw et al. 2002), and extracellular polymeric substances, among other substances. For example, acidophilic fungi can precipitate jarosite by decreasing $\mathrm{pH}$ down to the range between 2.5 and 2 by controlled biomineralization in merely 10 days (Oggerin $e t$ al., 2013). Such values are similar to the $\mathrm{pH}$ at which alunite destabilizes (>3; Acero et al., 2015). The sulfate thus released would then possibly be reduced by prokaryotic organisms (archaea or bacteria) that formed consortia with fungi, which can be found in a variety of geological environments (Konhauser et al., 1994; Chiacchiarini et al., 2010; Bengtson et al., 2014; Ivarsson et al., 2015), even at great depths within the continental crust (Drake et al., 2017). In fact, one of the most successful means for fungi to survive in the extreme sub-aerial environment is underpinned by their symbiotic associations with algae and cyanobacteria... [sic] (Rangel et al., 2018). For instance, strains of Leptospirillum ferrooxidans, Acidithiobacillus ferrooxidans, Acidithiobacillus thiooxidans, and Acidianus spp., among others, along with different species of the Aspergillus and Penicillium genus (at $\mathrm{pH}$ between 3 and 3.5) among filamentous fungi, yeast, and archaea consortia were determined for the Copahue-Caviahue geothermal system in 


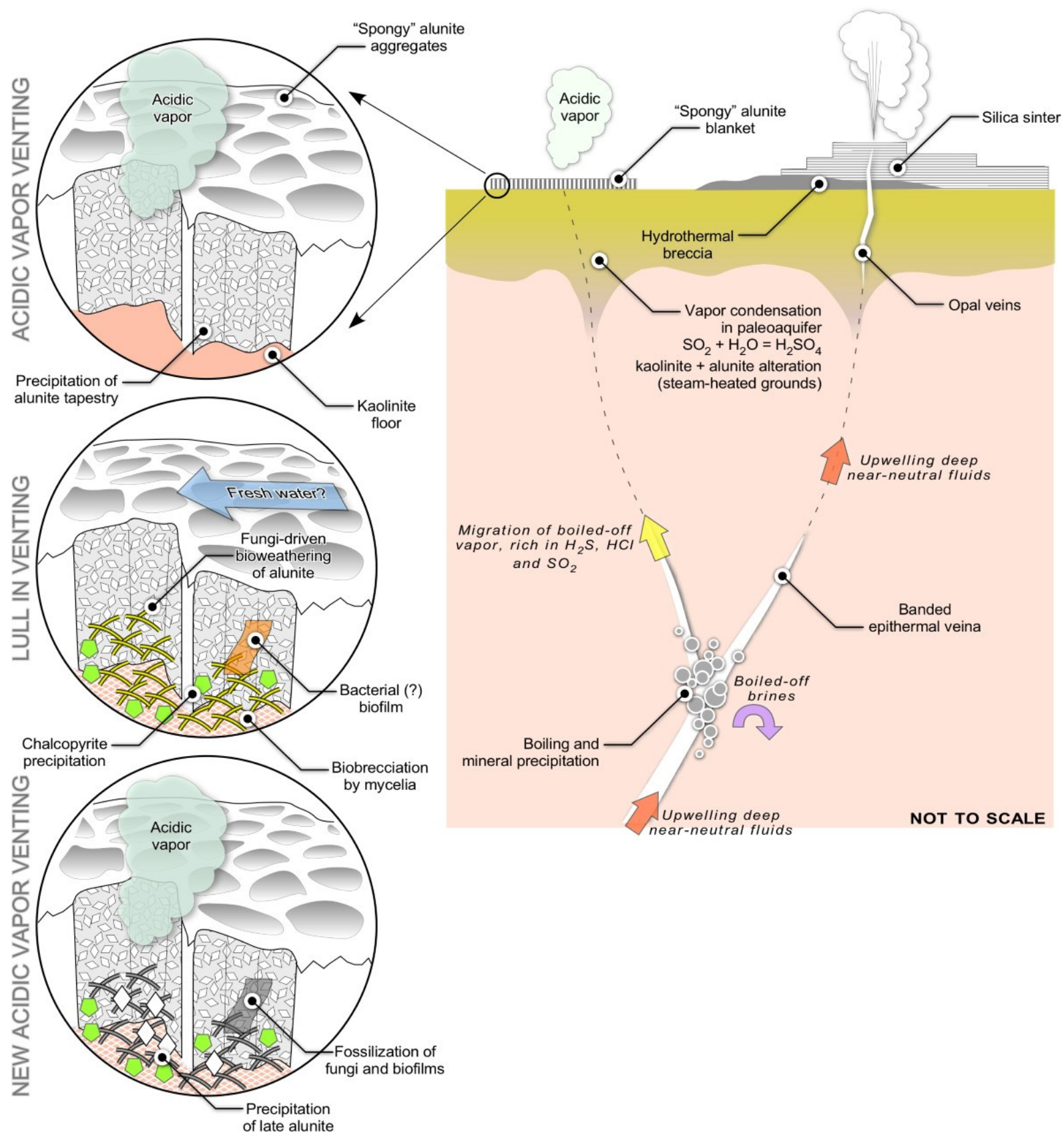

Figure 8 Conceptual sketch of the low-sulfidation epithermal deposits at Ixtacamaxtitlán (right) and of the general evolution of the spongy alunite blanket on steam-heated grounds in the area (left).

Argentina (Chiacchiarini et al., 2010). The occurrence of Aspergillus and Penicillium was also argued in the Te Whakarewarewatangaoteopetauaawahiao geothermal system in New Zealand (Jones et al., 2001a), as in waters with $p H<5$... fungi become dominant because they are adept at surviving in acidic water [sic] (Jones et al., 2001a). Therefore, the occurrence of fungi in a hot-spring environment can be tentatively constrained at $\mathrm{pH}$ between 3 and 5 .

\subsection{A ROLE FOR BAGTERIA AND THEIR GONSORTIA WITH FUNGI?}

Bacterial sulfate reduction could account for the precipitation of chalcopyrite, as in Figure $3 \mathrm{H}$. Could the cobweb-like structure in Figure $2 \mathrm{~F}$ be fossil evidence for bacterial consortia as biofilms? Similar structures at similar scales have been thus characterized both in the fossil record (e.g., 
Figure 1 in Schopf et al., 2015; also, Campbell et al., 2015a, 2015b; Fadel et al., 2017; Schopf et al., 2017) and as extant or recent consortia (Jannasch et al., 1994; Jones et al., 1999, 2001a, 2001b, 2004; also, see Figure 6 in Marano et al., 2016). Despite being prone to obliteration due to opal dehydration or recrystallization, acid etching, and other phenomena, bacteria fossils can even be preserved in silica sinters (e.g., Campbell et al., 2015a, 2015b). Also, Metallogenium bacteria involved in the oxidation of Fe or Mn may grow on the hyphal network as a result of indirect fungal biomineralization mediated by fungal exudates (Emerson $e t$ al., 1989; Furuta et al., 2007). Associated bacteria may nourish fungal mycelium, thus resulting in active bioweathering that is able to mobilize $\mathrm{Si}, \mathrm{Fe}$, $\mathrm{Mn}$, and $\mathrm{Mg}$, and stimulate the neoformation of clay minerals, among other silicates. The accumulation of the associated bacteria on hyphae may well lead to their preservation (Peckmann et al., 2008; Ivarsson et al., 2018). Bacterial communities associated with arbuscular mycorrhizal fungi assist the latter to complete the functions required for this association to succeed (Turrini et al., 2018). Arbuscular mycorrhizal fungi would then recruit specific bacterial populations capable of dissolving $\mathrm{P}$ from relatively insoluble sources when it is associated with $\mathrm{Al}$ and $\mathrm{Fe}$ in either acid or alkaline substrates (Turrini et al., 2018). However, there is a large gap in our understanding of the possible role of fungi in surficial environments where only Ascomycota and Basidiomycota, including strains of anaerobic fungi, have been identified in vent fluids (López-García et al., 2007) and Chytridiomycota in hydrothermal vents (Le Calvez et al., 2009). All in all, the occurrence of archaea or bacteria in consortium with fungi is likely even in steamheated environments.

Fungi and fungal remains and their interactions with minerals in epithermal deposits or geothermal systems, like those in the deposits at the El Deseado massif in Argentina (e.g., Coelomycetes, Microthyriales, Chytridiomycota, etc.; Massini et al., 2012, 2016), are barely subjects of thorough examination. As discussed earlier, there is room for research on sulfate release by fungal activity and subsequent sulfate reduction and precipitation as sulfides mediated by prokaryotes. Besides the obvious interest in characterizing such processes for microbiological disciplines, there is a reasonable possibility that significant concentrations of key metals occur in similar hydrothermal environments. The efficiency of such processes would then be dictated by the specific prokaryote-eukaryote consortia that could actually form in each case. Interestingly, as mentioned above, such consortia can be established in a broad range of depths, from the very paleosurface down to hundreds of meters deep. This means that the role of living organisms in mineral precipitation (and dissolution) can be more widespread than what is generally recognized in ore deposit studies. It is widely believed that extreme shifts toward very low $\delta^{34} \mathrm{~S}$ values in sulfides account for bacteria-mediated precipitation in a broad variety of types of mineral deposits or mineral systems (e.g., Miranda-Gasca et al., 1998; Camprubí et al., 2001; Conly et al., 2006; Tornos et al., 2008; Arning et al., 2009; Carrillo-Rosúa et al., 2014; Bonetti et al., 2015; Drake et al., 2015, 2017; Simpson et al., 2017; Zhao et al., 2018; Fazli et al., 2019; Holley et al., 2019). In many cases, mineral precipitation was produced hundreds of meters below the paleosurface and in contrasting geological environments, but the role of bacteria in them is not disputed. However, fungal contributions are undetectable unless it is illustrated by compelling petrographic evidence or experimental work. Might hydrothermal systems that can bear bacteria and archaea also bear fungi? As discussed earlier, it is most likely that they do, and they have been described together as agents for mineralization in geothermal sinters (Jones et al. 1999). Then, could fungal activity be held accountable for part of reactive sequences that are so common in sulfide associations? Chemolithotrophic bacteria such as Thiobacillus ferrooxidans and Thiobacillus thiooxidans are very effective in solubilizing sulfides, hence their industrial use in bioleaching technologies, whereas fungi are more effective in bioleaching of non-sulfide ores (Bosecker, 1997; Wei et al., 2013). Experimental studies with Aspergillus niger produced variable (if not contradictory) results in 
the dissolution of sulfides like sphalerite or galena, although the fungal dissolution of zinc and lead oxides, carbonates, or phosphates can be much easily and effectively achieved (Sayer et al., 1997, 1999; Sutjaritvorakul et al., 2013; Wei et al., 2013). Also, some metal-tolerant strains of mycorrhyzal fungi were actually able to solubilize some galena (Fomina et al., 2005) despite its recalcitrance. Most studies are directed to bioremediation and thus to assessing the ability of fungi to leach, accumulate, and immobilize metals (e.g., Gadd, 2010; Sabra et al., 2011; Wei et al., 2013; Cecchi et al., 2019). Such is the reason for focusing on the subsequent precipitation of other solids following the dissolution of sulfides, such as oxalates, instead of setting environments in which sulfur metals would be released into an aqueous phase. None of these is an easy task, as fungal interactions with metal sulfides have been much less studied and these are generally regarded as quite recalcitrant materials for fungi [sic] (Wei et al., 2013). Bioweathering of zinc sulfide minerals (sphalerite or wurtzite) by saprotrophic fungi (Aspergillus niger, Penicillium roqueforti, Beauveria caledonica, Serpula himantioides, Trichoderma versicolor and Trichoderma viride) is possible at room temperature and under specific conditions nonetheless (Wei et al., 2013). All in all, the definition of the role of fungi in the dissolution of sulfides is, to say the least, problematic. Studies in sulfate minerals are even scarcer than in sulfides, although Aspergillus niger has been documented as an agent of gypsum dissolution (Gharieb, 2000). However, the available experimental studies on this matter are carried out at surficial temperature because these organisms are envisaged as agents of industrial bioleaching or bioremediation. What if those experimental studies were run at temperatures compatible with those of mineralizing hydrothermal systems as long as fungi, which are only moderately thermophilic, can endure them?

\subsection{HYDROGEOGHEMICAL GONSTRAINTS TO THE CONSORTIA BETWEEN FUNGI AND BACTERIA OR ARGHAEA}

The activity of water further constrains the activity of microorganisms for it ranges between 0.611 and
0.755 for halophilic archaea or bacteria, while it ranges between 0.585 and 0.632 for fungi (Oren, 2013; Stevenson et al., 2015; Lee et al., 2018; Merino et al., 2019). This means that water activity could be narrowed down to a range between 0.611 and 0.632 upon the coexistence of fungi and bacteria or archaea, as suggested earlier. The microstructural and mineralogical evidence may allow us to establish two feasible scenarios for the colonization of the alunite layer: (1) fungi would have established alone (water activity between 0.585 and 0.632), or (2) fungi would have been forming consortia with bacteria or archaea (water activity between 0.611 and 0.632). We envisage both possibilities because plausible evidence for such consortia are not abundant and may correspond to very localized conditions. As discussed above, the occurrence of fungi in this environment can be tentatively constrained at $\mathrm{pH}$ between 3 and 5 and at temperatures between 50 and $100^{\circ} \mathrm{C}$. Such $\mathrm{pH}$ and temperature brackets are represented in Figure 5 as blue and yellow shades, respectively. As presented in section 4.2, we may position water in the three stages of evolution of the advanced argillic alteration assemblages in the Ixtacamaxtitlán area with respect to the subsaturated or supersaturated character of each mineral. Amorphous silica (opal) occurs as an early mineral in this association (stage 1), also fossilizes fungal remains and biofilms, and occurs as a late coating (stage 3), but it does not occur while the fungal consortia were alive (stage 2), and thus we assume that the water during that period was subsaturated in amorphous silica. Alunite and kaolinite occurrences are about the same as for opal, but both were equilibrated in the modeled water samples and are being dissolved both inorganically and organically during the lifespan of fungi and bacteria or archaea. Therefore, the evolutionary trajectory of water in this environment would (1) start in a steam-heated environment in which water was supersaturated in amorphous silica, kaolinite, and alunite (inside the amorphous silica supersaturation box and above the amorphous $\mathrm{SiO}_{2}$ equilibrium in Figure $5)$; (2) continue in a more mature environment, 
subsaturated in opal (outside the amorphous silica supersaturation box and below the amorphous $\mathrm{SiO}_{2}$ equilibrium in Figure 5); and (3) end back in a steam-heated environment in which water was supersaturated in opal.

The evolution from stage 1 to stage 2 can be achieved through different paths, and all of them lead to the subsaturation in amorphous silica in water. Path $\mathrm{A}$ in Figure 5 involves increasing $\mathrm{pH}$ at nearly constant temperature, which can be due to the incursion of upwelling hydrothermal fluids that underwent no boiling and perhaps with various degrees of interaction with preexisting acidic water. Path $\mathrm{B}$ involves increasing temperature at nearly constant $\mathrm{pH}$, which can be due to the influx of water similar to that of stage 1, only significantly hotter. Path $\mathrm{C}$ involves decreasing $\mathrm{pH}$ at nearly constant temperature, or dilution by acidic water, which is unlikely because such an extremely acidic environment would prevent the installation of any fungi or other organisms. Path D involves increasing $\mathrm{pH}$ while decreasing temperature, which would be compatible with an incursion of meteoric water during a momentary shutoff in the generation of boiled-off vapors. A combination of paths $\mathrm{A}$ and $\mathrm{B}$ (path $\mathrm{AB}$ ) involves increasing both $\mathrm{pH}$ and temperature, which would be compatible with an incursion of upwelling mature and hotter water. While remaining geologically plausible, those paths that lead to a hotter environment (paths $\mathrm{B}$ and $\mathrm{AB}$ ) would be hostile to the installation of fungi and other organisms unless the temperature remained below $\sim 100{ }^{\circ} \mathrm{C}$, but then such paths would not fulfill the requirement that the subsaturation in amorphous silica was achieved. Then, the most geobiologically plausible paths that led to stage 1 to stage 2 would be paths A and D (Figure 5). Finally, the hydrothermal system would evolve into a steam-heated system once more (stage 3), subsequently killing the life forms of stage 2 , with water supersaturated in opal, alunite and kaolinite that fossilized the fungal and bacterial/archaeal remains. Then, it would result that the most likely $\mathrm{pH}$ during stage 2 and the installation of fungal consortia between $\sim 3.2$ and $\sim 3.6$, at temperatures between 53 and $75^{\circ} \mathrm{C}$ (Figure 5).

It is necessary to clarify that $75^{\circ} \mathrm{C}$ is taken only as a reference value that represents the mean between the temperature span that would generally allow fungi to live, but it is in no way a maximum value. The minimum $\mathrm{pH}$ and temperature conditions correspond to the lowest values calculated for steam-heated waters at subsaturated conditions of amorphous silica, whereas the maximum $\mathrm{pH}$ and temperature conditions are the minimum $\mathrm{pH}$ calculated for peripheral waters and the referred temperature value, respectively.

Therefore, $\mathrm{pH}$ remained relatively low during stage 2, but its moderate increase would have sufficed to induce the subsaturation in amorphous silica (Figure 5) and the subsequent dissolution of kaolinite and alunite, and would favor the colonization of this environment by living organisms. Then, although steam-heated acidic waters remained the dominant type in the paleosurface, their mixing - albeit limited - with meteoric or upwelling less acidic waters could account for the necessary $\mathrm{pH}$ and temperature variations.

\section{Conclusions}

Spongy blankets that are mostly constituted by alunite-rich vertical tubular structures are interpreted to have been formed in a steam-heated environment that was associated with boiled-off acid vapors during the formation of low-sulfidation epithermal veins underneath, and share a paleosurface with silica sinters. Both blankets and sinters lie on a subhorizontal advanced argillic alteration assemblage whose characteristics support their generation in a shallow hypogene environment.

${ }^{40} \mathrm{Ar} /{ }^{39} \mathrm{Ar}$ age determinations in this paper (rhombohedral alunite crystals from an advanced argillic alteration assemblage due to a steamheated environment) and in the available literature firmly establish the formation of porphyry/skarn 
$\mathrm{Cu}-\mathrm{Mo}-\mathrm{Au}$ (middle Miocene) and low-sulfidation epithermal deposits (Pliocene) in Ixtacamaxtitlán as associated with the magmatic activity of the Trans-Mexican Volcanic Belt (TMVB).

However, the porphyry/skarn $\mathrm{Cu}-\mathrm{Mo}-\mathrm{Au}$ and low-sulfidation epithermal deposits in Ixtacamaxtitlán correspond to different stages in the evolution of the TMVB (first and third, respectively) and their ages indicate a $\sim 12$ My gap, which invalidates the notion of a continuum of some sort between them combined with exhumation (a.k.a. telescoping). Therefore, the space association between both sets of ore deposits demands an ultimate geological element for their overlapping, which has possibly to do with the structural configuration of this region - a possibility that is not explored in this paper.

This paper also provides comprehensive evidence for paleobiological fungal (and possibly bacterial) activity in gas-venting structures. Fungal biomineralization was possibly mediated by extracellular polymeric substances that allowed the crystallization of alunite grains on hyphal surfaces. Likewise, the fungal bioweathering of alunite and kaolinite by selective exudates resulted in dissolution grooves made by hyphal "bodydriven" weathering. There may be fungal acidophilic and thermophilic adaptations of extreme environments but, in this case, the symbiosis with bacteria or archaea could support the presence of fungal cohabitants.

Based on the hydrogeochemical modeling of present-day geothermal waters by means of the PHREEQG code, with regard to the stability of the kaolinite + alunite + amorphous silica (opal) association, we constrained the possible environmental conditions that prevailed during the installation of fungi and bacteria or archea consortia at $\mathrm{pH}$ between $\sim 3.2$ and $\sim 3.6$ and temperatures between 53 and $\sim 75^{\circ} \mathrm{C}$. Such conditions were possibly due to the incursion of either meteoric water (due to a lull in boiling underneath) or upwelling water equilibrated with host rocks ("mature") that did not experience boiling. These would have experienced mixing with steam-heated waters at some degree, as $\mathrm{pH}$ remained relatively low.

\section{Acknowledgements}

This paper constitutes a part of the dissertation of E.F.G., who acknowledges the support of CONACy T through a PhD grant. The Institute of Geology (IGL) of the National Autonomous University of Mexico (UNAM) is acknowledged for authorizing E.F.G. to carry on her $\mathrm{PhD}$ research along with her academic duties. Funding for this work was provided by CONACyT through research grant 155662 to A.C. and CONAGyT-SENER pt4.1 Gemex-EU to E.G.P. Additional funding was provided by the IGL UNAM, and the Center of Geosciences of the UNAM through personal allocations. SEM and SWIR analyses were performed with the kind assistance of Augusto A. Rodríguez-Díaz and Lilia Arana Salinas at the Institute of Geophysics of the UNAM. Also, Figure 1 was drawn with the assistance of Rodrigo Delgado Sánchez. This paper benefitted from the expert insight of Tawn Albinson (twice), Ignacio Eduardo Maldonado Mendoza, and Nathalie Séjalon-Delmas, through their formal reviews. Carl Nelson, Lisard Torró and Joaquín Proenza, as handling editors of this special issue, are thanked for their patience and insight.

\section{References}

Acero, P., Hudson-Edwards, K.A., Gale, J.D., 2015, Influence of $\mathrm{pH}$ and temperature on alunite dissolution: Rates, products and insights on mechanisms from atomistic simulation: Chemical Geology, 419, 1-9. https://doi. org/10.1016/j.chemgeo.2015.10.018

Arning, E.T., Birgel, D., Brunner, B., Peckmann, J., 2009, Bacterial formation of phosphatic laminites off Peru: Geobiology, 7, 295-307. https://doi. org/10.1111/j.1472-4669.2009.00197.x

Bengtson, S., Ivarsson, M. Astolfo, A., Belivanova, V., Broman, C., Marone, F., Stampanoni, M., 2014, Deep-biosphere consortium of fungi and prokaryotes in Eocene subseafloor basalts: Geobiology, 12, 489-496. https://doi. org/10.1111/gbi. 12100 
Bonnetti, G., Cuney, M., Michels, R., Truche, L., Malartre, F., Liu, X., Yang, J., 2015, The multiple roles of sulfate-reducing bacteria and $\mathrm{Fe}-\mathrm{Ti}$ oxides in the genesis of the Bayinwula roll front-type uranium deposit, Erlian basin, NE China: Economic Geology, 110, 1059-1081. https://doi.org/10.2113/ econgeo.110.4.1059

Bosecker, K., 1997, Bioleaching: Metal solubilization by microorganisms: FEMS Microbiology Reviews, 20, 591-604. https://doi.org/10.1111/j.1574-6976.1997. tb00340.x

Campbell, K.A., Guido, D.M., Gautret, P., Foucher, F., Ramboz, C., Westall, F., 2015a, Geyserite in hot-spring siliceous sinter: window on Earth's hottest terrestrial (paleo) environment and its extreme life: EarthScience Reviews, 148, 44-64. https://doi. org/10.1016/j.earscirev.2015.05.009

Campbell, K.A., Lynne, B.Y., Handley, K.M., Jordan, S., Farmer, J.D., Guido, D.M., Foucher, F., Turner, S., Perry, R.S., 2015b, Tracing biosignature preservation of geothermally silicified microbial textures into the geological record: Astrobiology, 15, 858-882. https://doi.org /10.1089/ ast.2015.1307

Camprubí, A., 2009, Major metallogenic provinces and epochs of Mexico: SGA News, 25, 1-21. https://e-sga.org/fileadmin/sga/ newsletter/news25/SGANews25.pdf

Camprubí, A., 2013, Tectonic and metallogenic history of Mexico, in Colpron, M., Bissig, T., Rusk, B.G., Thompson, J.F.H., (eds.), Tectonics, metallogeny, and discovery: the North American Cordillera and similar accretionary settings: Littleton, Colorado, USA, Society of Economic Geologists. Society of Economic Geologists Special Publication, 17, 201-243. https://doi. org/10.5382/SP.17.06

Camprubí, A., 2017, The metallogenic evolution in Mexico during the Mesozoic, and its bearing in the Cordillera of Western North
America: Ore Geology Reviews, 81, 1193-1214. https://doi.org/10.1016/j. oregeorev.2015.11.007

Camprubí, A., Albinson, T., 2006, Depósitos epitermales en México: actualización de su conocimiento y reclasificación empírica: Boletín de la Sociedad Geológica Mexicana, 58, 27-81. https://dx.doi.org/10.18268/ BSGM2006v58n 1a2

Camprubí, A., Albinson, T., 2007, Epithermal deposits in México - an update of current knowledge, and an empirical reclassification: The Geological Society of America Special Paper, 422, 377-415. https://doi.org/10.1130/2007.2422(14)

Camprubí, A., Cardellach, E., Canals, À., Lucchini, R., 2001. The La Guitarra Ag-Au low sulfidation epithermal deposit, Temascaltepec district, Mexico: fluid inclusion and stable isotope data, in Albinson, T., Nelson, G.E. (eds.), New mines and discoveries in Mexico and Central America: Littleton, Colorado, USA, Society of Economic Geologists. Society of Economic Geologists Special Publication, 8, 159-185. https://doi. org/10.5382/SP.08.11

Camprubí, A., Ferrari, L., Cosca, M.A., Cardellach, E., Canals, À., 2003, Ages of epithermal deposits in Mexico: Regional significance and links with the evolution of Tertiary volcanism: Economic Geology, 98, 1029-1037. http://dx.doi.org/10.2113/ gsecongeo.98.5.1029

Camprubí, A., González-Partida, E., Valencia, V.A., Barra, F., 2015, Geochronology of Mexican mineral deposits. I: the San Martín polymetallic skarn, Zacatecas: Boletín de la Sociedad Geológica Mexicana, 67, 119-122. https://dx.doi.org/10.18268/ BSGM2015v67n1a10

Camprubí, A., Albinson, T., Iriondo, A., 2016a, Geochronology of Mexican mineral deposits. V: the Peñón Blanco epithermal deposit, Durango: Boletín de la Sociedad 
Geológica Mexicana, 68, 365-370. https:// dx.doi.org/10.18268/BSGM2016v68n2a13

Camprubí, A., Iriondo, A., Martínez-López, M., Ramos-Rosique, A., 2016b, Geochronology of Mexican mineral deposits. IV: the Cinco Minas epithermal deposit, Jalisco: Boletín de la Sociedad Geológica Mexicana, 68, 357-364. https://dx.doi.org/10.18268/ BSGM2016v68n2a12

Camprubí, A., González-Partida, E., Alfonso, P., López-Martínez, M., Iriondo, A., CienfuegosAlvarado, E., Gutiérrez-Armendáriz, E., Morales-Puente, P., Canet, C., GonzálezRuiz, L., 2017a, The Late Cretaceous Guaynopa IOGG and Guaynopita porphyry copper deposits, Chihuahua, Mexico: Ore Geology Reviews, 81, 1096-1112. https:// doi.org/10.1016/j.oregeorev.2016.01.006

Camprubí, A., González-Partida, E., Torró, L., Alfonso, P., Miranda-Gasca, M.A., Martini, M., Canet, C., González-Sánchez, F., 2017b, Mesozoic volcanogenic massive sulfide (VMS) deposits in Mexico: Ore Geology Reviews, 81, 1066-1083. https://doi.org/10.1016/j. oregeorev.2015.07.027

Camprubí, A., Centeno-García, E., Tolson, G., Iriondo, A., Ortega, B., Bolaños, D., Abdullin, F., Portugal-Reyna, J.L., Ramos-Arias, M.A., 2018, Geochronology of Mexican mineral deposits. VII: the Peña Colorada magmatichydrothermal iron oxide deposit (IOCG "clan"), Colima: Boletín de la Sociedad Geológica Mexicana, 70, 633-674. https:// dx.doi.org/10.18268/BSGM2018v70n3a4

Camprubí, A., Cabrera-Roa, M.A., GonzálezPartida, E., Martínez-López, M., 2019, Geochronology of Mexican mineral deposits. VIII: the Zacatepec polymetallic skarn, Oaxaca: Boletín de la Sociedad Geológica Mexicana, 71, 207-218. https://dx.doi. org/10.18268/BSGM2019v71nla11

Carrasco-Núñez, G., Gómez-Tuena, A., Lozano, L., 1997, Geologic map of Cerro Grande volcano and surrounding area, central Mexico: Geological Society of America, Map and Chart Series, CH 081, 10.
Carrillo-Rosúa, J., Boyce, A.J., Morales-Ruano, S., Morata, D., Roberts, S., Munizaga, F., MorenoRodríguez, V., 2014, Extremely negative and inhomogeneous sulfur isotope signatures in Cretaceous Chilean manto-type $\mathrm{Cu}-(\mathrm{Ag})$ deposits, Coastal Range of central Chile: Ore Geology Reviews, 56, 13-24. https://doi. org/10.1016/j.oregeorev.2013.06.013

Catchpole, H., Kouzmanov, K., Fontboté, L., Guillong, M., Heinrich, G.A., 2011, Fluid evolution in zoned Cordilleran polymetallic veins - Insights from microthermometry and LA-ICP-MS of fluid inclusions: Chemical Geology, 281, 293-304. https://doi. org/10.1016/j.chemgeo.2010.12.016

Cecchi, G., Ceci, A., Marescotti, P., Persiani, A.M., Di Piazza, S., Zotti, M., 2019, Interactions among microfungi and pyrite-chalcopyrite mineralizations: tolerance, mineral bioleaching, and metal bioaccumulation: Mycological Progress, 18, 415-423. https:// doi.org/10.1007/s1 1557-018-01466-y

Chiacchiarini, P., Lavalle, L., Giaveno, A., Donati, E., 2010, First assessment of acidophilic microorganisms from geothermal CopahueCaviahue system: Hydrometallurgy, 104, 334-341. https://doi.org/10.1016/j. hydromet.2010.02.020

Clark, K.F., Fitch, D.C., 2009, Evolución de depositos metálicos en tiempo y espacio en Mexico, in Clark, K.F., Salas-Pizá, G., Cubillas-Estrada, R., eds., Geología Económica de México, II: Pachuca, Hidalgo, Servicio Geológico Mexicano, 62-133.

Conly, A.G., Beaudoin, G., Scott, S.D., 2006, Isotopic constraints on fluid evolution and precipitation mechanisms for the Boléo $\mathrm{Cu}-\mathrm{Co}-\mathrm{Zn}$ district, Mexico: Mineralium Deposita, 41, 127-151. https://doi. org/10.1007/s00126-005-0045-3

Connell, L.B., Barrett, A.W., Templeton, A., Staudigel, H., 2009, Fungal diversity associated with an active deep sea volcano: Vailulu'u seamount, Samoa: Geomicrobiology, 26, 597-605. https://doi. org/10.1080/01490450903316174 
Cooke, D.R., Deyell, G.L., Waters, P.J., Gonzales, R.I., Zaw, K., 2011, Evidence for magmatichydrothermal fluids and ore-forming processes in epithermal and porphyry deposits of the Baguio district, Philippines: Economic Geology, 106, 1399-1424. http:// dx.doi.org/10.2113/econgeo.106.8.1399

Cuadros, J., 2017, Clay minerals interaction with microorganisms: a review: Clay Minerals, 52, 235-261. https://doi.org/10.1180/ claymin.2017.052.2.05

Cuadros, J., Afsin, B., Michalski, J.R., Ardakani, M., 2012, Fast, microscale-controlled weathering of rhyolitic obsidian to quartz and alunite: Earth and Planetary Science Letters, 353-354, 156-162. https://doi. org/10.1016/j.epsl.2012.08.009

Dekov, V.M., Rouxel, O., Kouzmanov, K., Bindi, L., Asael, D., Fouquet, Y., Etoubleau, J., Burgaud, G., Wälle, M., 2016, Enargiteluzonite hydrothermal vents in Manus Back-Arc Basin: Submarine analogues of high-sulfidation epithermal mineralization: Chemical Geology, 438, 36-57. https://doi. org/10.1016/j.chemgeo.2016.05.021

Dill, H.G., Dohrmann, R., Kaufhold, S., Çiçek, G., 2015, Mineralogical, chemical and micromorphological studies of the argillic alteration zone of the epithermal gold deposit Ovacik, Western Turkey: Tools for applied and genetic economic geology: Journal of Geochemical Exploration, 148, 105-127. https://doi.org/10.1016/j. gexplo.2014.08.016

Drake, H., Tullborg, E.-L., Whitehouse, M., Sandberg, B., Blomfeldt, T., Åström, M.E., 2015, Extreme fractionation and micro-scale variation of sulphur isotopes during bacterial sulphate reduction in deep groundwater systems: Geochimica et Cosmochimica Acta, 161, 1-18. https://doi.org/10.1016/j. gca.2015.04.014

Drake, H., Ivarsson, M., Bengtson, S., Heim, C., Siljeström, S., Whitehouse, M.J., Broman, C., Belivanova, V., Åström, M.E., 2017,
Anaerobic consortia of fungi and sulfate reducing bacteria in deep granite fractures: Nature Communications, 8(1), 55. https:// doi.org/10.1038/s41467-017-00094-6

Ehrlich, H.L., 1998, Geomicrobiology: its significance for geology: EarthScience Reviews, 45, 45-60. https://doi. org/10.1016/S0012-8252(98)00034-8

Emerson, D., Garen, R.E., Ghiorse, W.C., 1989, Formation of Metallogenium-like structures by a manganese-oxiding fungus: Archives of Microbiology, 151, 223-231. https://doi. org/10.1007/BF00413134

Enríquez, E., Iriondo, A., Camprubí, A., 2018, Geochronology of Mexican mineral deposits. VI: the Tayoltita low-sulfidation epithermal district, Durango and Sinaloa: Boletín de la Sociedad Geológica Mexicana, 70, 531-547. https://dx.doi.org/10.18268/ BSGM2018v70n2a13

Fadel, A., Lepot, K., Busigny, V., Addad, A., Troadec, D., 2017, Iron mineralization and taphonomy of microfossils of the 2.45-2.21 Ga Turee Creek Group, Western Australia: Precambrian Research, 298, 530-551. https://doi.org/10.1016/j. precamres.2017.07.003

Farfán-Panamá, J.L., Camprubí, A., GonzálezPartida, E., Iriondo, A., González-Torres, E.A., 2015, Geochronology of Mexican mineral deposits. III: the Taxco epithermal deposit, Guerrero: Boletín de la Sociedad Geológica Mexicana, 67, 357-366. https:// dx.doi.org/10.18268/BSGM2015v67n2a16

Fayers, S.R., Trewin, N.H., 2004, A review of the palaeoenvironments and biota of the Windyfield chert: Transactions of the Royal Society of Edinburgh, Earth Sciences, 94, 325-339. https://doi.org/10.1017/ S0263593300000729

Fazli, S., Taghipour, B., Moore, F., Lentz, D.R., 2019, Fluid inclusions, $\mathrm{S}$ isotopes, and $\mathrm{Pb}$ isotopes characteristics of the Kuh-e-Surmeh carbonate-hosted $\mathrm{Zn}-\mathrm{Pb}$ deposit in the Zagros Fold Belt, southwest Iran: Implications 
for the source of metals and sulfur and MVT genetic model: Ore Geology Reviews, 109, 615-629. https://doi.org/10.1016/j. oregeorev.2019.04.006

Fitz-Díaz, E., Lawton, T.F., Juárez-Arriaga, E., Chávez-Cabello, G., 2018, The CretaceousPaleogene Mexican orogen: Structure, basin development, magmatism and tectonics: Earth-Science Reviews, 183, 56-84. https:// doi.org/10.1016/j.earscirev.2017.03.002

Fomina, M.A., Alexander, I.J., Colpaert, J.V., Gadd, G.M., 2005, Solubilization of toxic metal minerals and metal tolerance of mycorrhizal fungi: Soil Biology and Biochemistry, 37, 851-866. https://doi. org/10.1016/j.soilbio.2004.10.013

Franchini, M., McFarlane, C., Maydagán, L., Reich, M., Lentz, D.R., Meinert, L., Bouhier, V., 2015, Trace metals in pyrite and marcasite from the Agua Rica porphyry-high sulfidation epithermal deposit, Catamarca, Argentina: Textural features and metal zoning at the porphyry to epithermal transition: Ore Geology Reviews, 66, 366-387. https://doi. org/10.1016/j.oregeorev.2014.10.022

Fuentes-Guzmán, E., González-Partida, E., Camprubí, A., Hernández-Avilés, G., Gabites, J., Iriondo, A., Ruggieri, G., LópezMartínez, M., 2020a, The Miocene TatatilaLas Minas IOCG skarn deposits (Veracruz) as a result of adakitic magmatism in the Trans-Mexican Volcanic Belt: Boletín de la Sociedad Geológica Mexicana, 72 (3), A110520. http://dx.doi.org/10.18268/ BSGM2020v72n3a110520

Fuentes-Guzmán, E., Camprubí, A., Gabites, J., González-Partida, E., 2020b, The Pliocene Xoconostle high sulfidation epithermal deposit in the Trans-Mexican Volcanic Belt: Preliminary study: Boletín de la Sociedad Geológica Mexicana, 72 (3), A260520. http://dx.doi.org/10.18268/ BSGM2020v72n3a260520

Furuta, S., Yoshida, M., Okamoto, T., Wakabayashi, T., Ichise, S., Aoki, S., Kohno,
T., Miyajima, T., 2007, Morphological variations of a manganese-oxidizing microorganism Metallogenium observed in the developmental process of cultures collected from Lake Biwa waters: Japanese Journal of Limnology, 68, 433-441. https:// doi.org/10.3739/rikusui.68.433

Gadanho, M., Sampaio, J.P., 2005, Occurrence and diversity of yeasts in the Mid-Atlantic Ridge hydrothermal fields neat the Azores archipelago: Microbial Ecology, 50, 408-417. https://doi.org/10.1007/ s00248-005-0195-y

Gadd, G.M., 2010, Metals, minerals and microbes: geomicrobiologyand bioremediation: Microbiology, 156, 609-643. https://doi. org/10.1099/mic.0.037143-0

Gharieb, M.M., 2000, Nutritional effects on oxalic acid production and solubilization of gypsum by Aspergillus niger: Mycological Research, 104, 550-556. https://doi.org/10.1017/ S0953756299001707

Gómez-Tuena, A., Carrasco-Núñez, G., 2000, Cerro Grande volcano: The evolution of a Miocene stratocone in the early TransMexican Volcanic Belt: Tectonophysics, 318, 249-280. https://doi.org/10.1016/ S0040-1951(99)00314-5

Gómez-Tuena, A., La Gatta, A., Langmuir, C., Goldstein, S., Ortega-Gutiérrez, F., Carrasco-Núñez, G., 2003, Temporal control of subduction magmatism in the Eastern Trans-Mexican Volcanic Belt: mantle sources, slab contributions and crustal contamination: Geochemistry, Geophysics, Geosystems, 4 (8), 8912. https://doi. org/10.1029/2003GC000524

Gómez-Tuena, A., Orozco-Esquivel, M.T., Ferrari, L., 2005, Petrogénesis ígnea de la Faja Volcánica Transmexicana: Boletín de la Sociedad Geológica Mexicana, 57, 227-283. https://dx.doi.org/10.18268/ BSGM2005v57n3a2

Gómez-Tuena, A., Orozco-Esquivel, M.T., Ferrari, L., 2007, Igneous petrogenesis of 
the Trans-Mexican Volcanic Belt, in AlanizÁlvarez, S.A., Nieto-Samaniego, Á.F., eds., Geology of México: Celebrating the centenary of the Geological Society of México: Boulder, Colorado, USA, The Geological Society of America. Geological Society of America Special Paper, 422, 129-182. https://doi. org/10.1130/2007.2422(05)

González-Jiménez, J.M., Camprubí, A., Colás, V., Griffin, W.L., Proenza, J.A., Belousova, E., Centeno-García E., O’Reilly, S.Y., Talavera, C., Farré-de-Pablo, J., Satsukawa, T., 2017a, The recycling of chromitites in ophiolites from southwestern North America: Lithos, 294-295, 53-72. https://doi.org/10.1016/j. lithos.2017.09.020

González-Jiménez, J.M., Proenza, J.A., Martini, M., Camprubí, A., Griffin, W.L., O’Reilly, S.Y., Pearson, N.J., 2017 b, Deposits associated with ultramafic-mafic complexes in Mexico: the Loma Baya case: Ore Geology Reviews, 81, 1053-1065. https://doi.org/10.1016/j. oregeorev.2015.05.014

González-Partida, E., Carrillo-Chávez, A., Levresse, G., Tello-Hinojosa, E., VenegasSalgado, S., Ramírez-Silva, G., Pal-Verma, M., Tritlla, J., Camprubí, A., 2005, Hydrogeochemistry and isotopic fluid evolution of the Los Azufres geothermal field, Central Mexico: Applied Geochemistry, 20, 23-39. https://doi.org/10.1016/j. apgeochem.2004.07.006

Gómez-Alarcón, G., Muñoz, M.L., Flores, M., 1994, Excretion of organic acids by fungal strains isolated from decayed limestone. International Biodeterioration \& Biodegradation, 34, 169-180. https://doi. org/10.1016/0964-8305(94)90006-X

Gorbushina,A.A., 2007,Life on the rocks:Environmental Microbiology, 9, 1613-1631. https://doi. org/10.1111/j.1462-2920.2007.01301.x

Gross, S., Robbins, E.I., 2000, Acidophilic and acid-tolerant fungi and yeasts: Hydrobiologia, 433, 91-109. https://dx.doi. org/10.1023/A:1004014603333
Hamilton, A.R., Campbell, K.A., Rowland, J.V., Barker, S., Guido, D.M., 2019, Fossilised geothermal surface features of the Whitianga Volcanic Centre (Miocene), Coromandel Volcanic Zone, New Zealand: Controls and characteristics: Journal of Volcanology and Geothermal Research, 381, 209-226. https://doi.org/10.1016/j. jvolgeores.2019.06.009

Hedenquist, J.W., Taran, Y.A., 2013, Modeling the formation of advanced argillic lithocaps: Volcanic vapor condensation above porphyry intrusions: Economic Geology, 108, 1523-1540. https://dx.doi.org/10.2113/ econgeo.108.7.1523

Hedenquist, J.W., Arribas, A. Jr., Urien-Gonzalez, E., 2000, Exploration for epithermal gold deposits, in Hagemann, S.G., Brown, P.E. (eds.), Gold in 2000: Reviews in Economic Geology, 13, 245-277. https://doi. org/10.5382/Rev. 13.07

Hirsch, P., Eckhardt, F.E.W., Palmer, R.J. Jr., 1995, Fungi active in weathering of rock and stone monuments: Canadian Journal of Botany, 73, 1384-1390. https://doi.org/10.1139/b95-401

Holley, E.A., Lowe, J.A., Johnson, C.A., Pribil, M.J., 2019, Magmatic-hydrothermal gold mineralization at the Lone Tree mine, Battle Mountain District, Nevada: Economic Geology, 114, 811-856. https://doi. org/10.5382/econgeo.4665

Hronsky, J.M.A., Groves, D.I., 2008, Science of targeting: Definition, strategies, targeting and performance measurement: Australian Journal of Earth Sciences, 55, 3-12. https:// doi.org/10.1080/08120090701581356

Hronsky, J.M.A., Groves, D.I., Loucks, R.R., Begg, G.C., 2012, A unified model for gold mineralisation in accretionary orogens and implications for regional-scale exploration targeting methods: Mineralium Deposita, 47, 339-358. https://doi.org/10.1007/ s00126-012-0402-y

Imer, A., Richards, J.P., Muehlenbachs, K., 2016, Hydrothermal evolution of the Çöpler 
porphyry-epithermal $\mathrm{Au}$ deposit, Erzincan Province, Central Eastern Turkey: Economic Geology, 111, 1619-1658. http://dx.doi. org/10.2113/econgeo.111.7.1619

Ivarsson, M., Bengtson, S., Belivanova, V., Stampanoni, M., Marone, F., Tehler, A., 2012, Fossilized fungi in subseafloor Eocene basalts: Geology, 40, 163-166. https://doi. org/10.1130/G32590.1

Ivarsson M, Bengtson S, Skogby H, Lazor P, Broman C, Belivanova V, Marone, F, 2015, A fungal-prokaryotic consortium at the basaltzeolite interface in subseafloor igneous crust: PLoS ONE 10(10): e0140106. https://doi. org/10.1371/journal.pone.0140106

Ivarsson, M., Bengtson, S., Neubeck, A., 2016, The igneous oceanic crust - Earth's largest fungal habitat?: Fungal Ecology, 20, 249-255. https://doi.org/10.1016/j. funeco.2016.01.009

Ivarsson, M., Bengtson, S., Drake, H., Francis, W., 2018, Fungi in Deep Subsurface Environments: Advances in Applied Microbiology, 102, 83-116. https://doi. org/10.1016/bs.aambs.2017.11.001

Ivarsson, M., Kilias, S.P., Broman, C., Neubeck, A., Drake, H., Chi Fru, E., Bengtson, S., Naden, J., Detsi, K., Whitehouse, M.J., 2019, Exceptional preservation of fungi as H2-bearing fluid inclusions in an Early Quaternary paleo-hydrothermal system at Ape Vani, Milos, Greece: Minerals, 9, 749. https://doi.org/10.3390/min9120749

Jannasch, H.W., Nelson, D.C., Wirsen, G.O., 1994, Massive natural occurrence of unusually large bacteria (Beggiatoa sp.) at a hydrothermal deep-sea vent site: Nature, 342, 834-836. https://doi. org/10.1038/342834a0

Jansen, N.H., Gemmell, J.B., Chang, Z., Cooke, D.R., Jourdan, F., Creaser, R.A., Hollings, P., 2017, Geology and genesis of the Cerro la Mina porphyry-high sulfidation $\mathrm{Au}(\mathrm{Cu}-$ Mo) prospect, Mexico: Economic Geology, 112, 799-827. https://dx.doi.org/10.2113/ econgeo.112.4.799
Jones, B., Renaut, R.W., Rosen, M.R., 1999, Role of fungi in the formation of siliceous coated grains, Waiotapu geothermal area, North Island, New Zealand: Palaios, 14, 475-492. https://dx.doi.org/10.2310/3515398

Jones, B., Renaut, R.W., Rosen, M.R., 2000, Stromatolites forming in acidic hot-spring waters, North Island, New Zealand: Palaios, 15,450-475.https://doi.org/10.1669/0883$1351(2000) 015<0450$ : SFIAHS $>2$. 0 . $\mathrm{CO} ; 2$

Jones, B., Renaut, R.W., Rosen, M.R., 2001a, "Geyser eggs" from Te Whakarewarewatangaoteopetauaawahiao, North Island, New Zealand: Journal of Sedimentary Research, 71, 190-204. http:/ / dx.doi.org/10.1306/060100710190

Jones, B., Renaut, R.W., Rosen, M.R., 2001b, Microbial construction of siliceous stalactites at geysers and hot springs: Examples from the Whakarewarewa geothermal area, North Island, New Zealand: Palaios, 16, 7394. https://doi.org/10.1669/08831351 (2001)0 16<0073:MGOSSA>2.0. $\mathrm{CO} ; 2$

Jones, B., Renaut, R.W., Rosen, M.R., 2004, Taxonomic fidelity of silicified filamentous microbes from hot-spring systems in the Taupo Volcanic Zone, North Island, New Zealand: Transactions of the Royal Society of Edinburgh: Earth Sciences, 94, 475-483. https://doi.org/10.1017/ S0263593300000821

Konhauser, K.O., Fyfe, W.S., Schultze-Lam, S., Ferris, F.G., Beveridge, T.J., 1994, Iron phosphate precipitation by epilithic microbial biofilms in Arctic Canada: Canadian Journal of Earth Sciences, 31,1320-1324. https:// doi.org/10.1139/e94-114

Konhauser, K.O., Jones, B., Phoenix, V.R., Ferris, G., Renaut, R.W., 2004, The microbial role in hot spring silicification: Ambio, 33, 552-558. https://doi. org/10.1579/0044-7447-33.8.552

Koppers, A.P., 2002, ArArCALC - software for ${ }^{40} \mathrm{Ar} /{ }^{39} \mathrm{Ar}$ age calculations: Computers and 
Geosciences, 28, 605-619. https://doi. org/10.1016/S0098-3004(01)00095-4

Kuiper, K.F., Deino, A, Hilgen, F.J., Krijgsman, W., Renne, P.R., Wijbrans, J.R., 2008, Synchronizing rock clocks of earth history: Science, 320, 500. https://doi.org/10.1126/ science. 1154339

Lang, B., Steinitz, G., Sawkins, F.J., Simmons, S.F., 1988, K-Ar age studies in the Fresnillo silver district, Zacatecas, Mexico: Economic Geology, 83, 1642-1646. http://dx.doi. org/10.2113/gsecongeo.83.8.1642

Le Calvez, T., Burgaud, G., Mahé, S., Barbier, G., Vandenkoornhuyse, P., 2019, Fungal diversity in deep-sea hydrothermal ecosystems: Applied and Environmental Microbiology, 75, 6415-6421. https://doi.org/10.1128/ AEM.00653-09

Lee, G.J.D., McMullan, P.E., O’Kane, C.J., Stevenson, A., Santos, I.C., Roy, C., Ghosh, W., Mancinelli, R.L., Mormile, M.R., McMullan, G., Banciu, H.L., Fares, M.A., Benison, K.G., Oren, A., Dyall-Smith, M.L., Hallsworth, J.E., 2018, NaCl-saturated brines are thermodynamically moderate, rather than extreme, microbial habitats: FEMS Microbiology Reviews, 42, 672-693. https://doi.org/10.1093/femsre/fuy026

López-García, P., Vereshchaka, A., Moreia, D., 2006, Eukaryotic diversity associated with carbonates and fluid-seawater interface in Lost City hydrothermal field: Environmental Microbiology, 9, 546-554. https://doi. org/10.1111/j.1462-2920.2006.01158.x

Ludwig, K.R, 2003, Isoplot 3.09, A Geochronological Toolkit for Microsoft Excel. Berkeley Geochronology Center, Special Publication, 4.

Marano, F., Di Rita, F., Palombo, M.R., Ellwood, N.T.W., Bruno, L., 2016, A first report of biodeterioration caused by cyanobacterial biofilms of exposed fossil bones: A case study of the middle Pleistocene site of La Polledrara di Cecanibbio (Rome, Italy): International Biodeterioration \& Biodegradation, 106, 67-74. https://doi.org/10.1016/j. ibiod.2015.10.004
Martínez-Reyes, JJ., Camprubí, A., Uysal, I.T., Iriondo, A., González-Partida, E., 2015, Geochronology of Mexican mineral deposits. II: Veta Madre and Sierra epithermal vein systems, Guanajuato district: Boletín de la Sociedad Geológica Mexicana, 67, 349-355. https://dx.doi.org/10.18268/ BSGM2015v67n2a15

Massini, J.G., Channing, A., Guido, D.M., Zamuner, A.B., 2012, First report of fungi and fungus-like organisms from Mesozoic hot springs: Palaios, 27, 55-62. https://doi. org/10.2110/palo.2011.p11-076r

Massini, J.G., Escapa, I.H., Guido, D.M., Channing, A., 2016, First glimpse of the silicified hot spring biota from a new Jurassic chert deposit in the Deseado Massif, Patagonia, Argentina: Ameghiniana, 53, 205-230. https://doi.org/10.5710/ AMGH.26.01.2016.2916

McCuaig, T.C., Beresford, S., Hronsky, J., 2010, Translating the mineral systems approach into an effective exploration targeting system: Ore Geology Reviews, 38, 128-138. https:// doi.org/10.1016/j.oregeorev.2010.05.008

McKee, E.H., Dreier,J.E., Noble, D.C., 1992, Early Miocene hydrothermal activity at PachucaReal del Monte, Mexico: an example of space-time association of volcanism and epithermal Ag-Au mineralization: Economic Geology, 87, 1635-1637. http://dx.doi. org/10.2113/gsecongeo.87.6.1635

Merino, N., Aronson, H.S., Bojanova, D.P., Feyhl-Buska, J., Wong, M.L., Zhang, S., Giovannelli, D., 2019, Living at the extremes: Extremophiles and the limits of life in a planetary context: Frontiers in Microbiology, 10, 780. https://doi.org/10.3389/fmicb.2019.00780

Miranda-Gasca, M.A., Gómez-Caballero, J.A., Eastoe, C.J., 1998, Borate deposits of northern Sonora, Mexico: stratigraphy, tectonics, stable isotopes, and fluid inclusions: Economic Geology, 93, 510-523. https:// dx.doi.org/10.2113/gsecongeo.93.4.510

Morales-Ramírez, J.M., 2002, Geología y metalogenia del depósito de Au-Ag-caolín de Ixtacamaxtitlán (edo. De Puebla, México). 
Facultad de Ingeniería, Universidad Nacional Autónoma de México, unpublished BSc thesis, 153 p. 132.248.9.195/ ppt2002/0313157/Index.html

Morales-Ramírez, J.M., Tritlla, J., Camprubí, A., Corona-Esquivel, R., 2003, Fluid origin of the Ixtacamaxtitlán hydrothermal deposits (Puebla State, Mexico): Journal of Geochemical Exploration, 78-79, 653-657. https://doi.org/10.1016/ S0375-6742(03)00139-0

Müller, B., Burgstaller, W., Strasser, H., Zanella, A., Schinner, F., 1995, Leaching of zinc from an industrial filter dust with Penicillium, Pseudomonas and Corynebacterium: citric acid is the leaching agent rather than amino acids: Journal of Industrial Microbiology, 14, 208-212. https://doi.org/10.1007/ BF01569929

Oggerin, M., Tornos, F., Rodríguez, N., Moral, C., Sánchez-Román, M., Amils, R., 2013, Specific jarosite biomineralization by Purpureocillium lilacinum, an acidophilic fungusisolatedfrom Río Tinto:Environmental Microbiology, 15, 2228-2237. https://doi. org//10.1111/1462-2920.12094.

Oren, A., 2013, Life in magnesium- and calciumrich hypersaline environments: salt stress by chaotropic ions, in Seckbach, J., Oren, A., Stan-Lotter, H. (eds.) Polyextremophiles. Cellular Origin, Life in Extreme Habitats and Astrobiology, v. 27: Dordrecht, The Netherlands, Springer, 215-232. https://doi. org/10.1007/978-94-007-6488-0_8.

Parkhurst, D.L., Appelo, C.A.J., 2013, Description of input and examples for PHREEQC version 3. A computer program for speciation, batch reaction, one dimensional transport, and inverse geochemical calculations, in U.S. Geological Survey (Ed.), Techniques and Methods, Book 6: Denver, Colorado, USA, U.S. Geological Survey, Chap. A43. https:// doi.org/10.3133/tm6A43

Peckmann,J.,Bach,W.,Behrens,K., Reitner,J., 2008, Putative cryptoendolithic life in Devonian pillow basalt, Rheinisches Schiefergebirge, Germany: Geobiology 6, 125-135. https:// doi.org/10.1111/j.1472-4669.2007.00131.x Peng, Y.W., Gu, X.X., Lv, P.R., Zhang, Y.M., Cheng, W.B., Wang, X.L., 2017, Genesis and tectonic setting of the Late Devonian Tawuerbieke gold deposit in the Tulasu ore cluster, western Tianshan, Xinjiang, China: International Geology Review, 59, 13441368. https://doi.org/10.1080/00206814.2 016.1236354

Poliquin, M.J., 2009, Geology, geochemistry and age of intrusion-related mineralisation in Eastern Mexico: Exeter, U.K., University of Exeter, unpublished $\mathrm{PhD}$ dissertation, $398 \mathrm{p}$. http://hdl.handle.net/10036/108354

Rangel, D.E.N., Finlay, R.D., Hallsworth, J.E., Dadachova, E., Gadd, G.M., 2018, Fungal strategies for dealing with environment- and agriculture-induced stresses: Fungal Biology, 122, 602-612. https://doi.org/10.1016/j. funbio.2018.02.002

Rasmussen, B., 2000, Filamentous microfossils in a 3,235-million-year-old volcanogenic massive sulphide deposit: Nature, 405 (6787), 676679. https://doi.org/10.1038/35015063

Renshaw, J.C., Robson, G.D., Trinci, A.P.J., Wiebe, M.G., Livens, F.R., Collison, D., Taylor, R.J., 2002, Fungal siderophores: structure, functions and applications. Mycological Research, 106, 1123-1142. https://doi. org/10.1017/S0953756202006548

Sabra, N., Dubourguier, H.-C., Duval, M.-N., Hamieh, T., 2011, Study of canal sediments contaminated with heavy metals: Fungal versus bacterial bioleaching techniques: Environmental Technology, 32, 1307-1324. https://doi.org/10.1080/09593330.2010.536782

Sayer, J.A., Kierans, M., Gadd, G.M., 1997, Solubilisation of some naturally occurring metal-bearing minerals, limescale and lead phosphate by Aspergillus niger: FEMS Microbiology Letters, 154, 29-35. https:// doi.org/10.1111/j.1574-6968.1997. tb12620.x 
Sayer, J.A., Cotter-Howells, J.D., Watson, C., Hillier, S., Gadd, G.M., 1999, Lead mineral transformation by fungi: Current Biology, 9, 691-694. https://doi.org/10.1016/ S0960-9822(99)80309-1

Schopf, J.W., Kudryavtsev, A.B., Walter, M.R., Van Kranendonk, M.J., Williford, K.H., Kozdon, R., Valley, J.W., Gallardo, V.A., Espinoza, C., Flannery, D.T., 2015, Sulfurcycling fossil bacteria from the 1.8-Ga Duck Creek Formation provide promising evidence of evolution's null hypothesis: Proceedings of the National Academy of Sciences of the United States of America, 112, 2087-2092. https://doi.org/10.1073/pnas.1419241112

Schopf, J.W., Kudryavtsev, A.B., Osterhout, J.T., Williford, K.H., Kitajima, K., Valley, J.W., Sugitani, K., 2017, An anaerobic 3400 $\mathrm{Ma}$ shallow-water microbial consortium: Presumptive evidence of Earth's Paleoarchean anoxic atmosphere: Precambrian Research, 299, 309-318. https://doi.org/10.1016/j. precamres.2017.07.021

Sillitoe, R.H., 1993, Epithermal models: genetic types, geometrical controls and shallow features, in Kirkham, R.V., Sinclair, W.D., Thorpe, R.I., Duke, J.M. (eds.), Mineral Deposit Modeling: Geological Association of Canada Special Paper, 40, 403-417.

Sillitoe, R.H., 2010, Porphyry copper systems: Economic Geology, 105, 3-41. http://dx.doi. org/10.2113/gsecongeo.105.1.3

Sillitoe, R.H., 2015, Epithermal paleosurfaces: Mineralium Deposita, 50, 767-793. https:// doi.org/10.1007/s00126-015-0614-z

Simpson, M.P., Mauk, J.L., Kendrick, R.G., 2004, Telescoped porphyry-style and epithermal veins and alteration at the central Maratoto Valley prospect, Hauraki goldfield, New Zealand: New Zealand Journal of Geology and Geophysics, 47, 39-56. https://doi.org/ 10.1080/00288306.2004.9515036

Simpson, S.L., Boyce, A.J., Lambert, P., Lindgren, P., Lee, M.R., 2017, Evidence for an impactinduced biosphere from the $834 \mathrm{~S}$ signature of sulphides in the Rochechouart impact structure, France: Earth and Planetary Science Letters, 460, 192-200. https://doi. org/10.1016/j.epsl.2016.12.023

Spectral International Inc., 1994, SWIR spectral mineral identification system and spectral database SPECMINTM, volume II: Integrated Spectronics, Colorado, USA.

Sterflinger, K., 2000, Fungi as geologic agents: GeomicrobiologyJournal, 17,97-124,https:// doi.org/10.1080/01490450050023791

Stevenson, A., Cray, J. A., Williams, J. P., Santos, R., Sahay, R., Neuenkirchen, N., McClure, C.D., Grant, I.R., Houghton, J.D., Quinn, J.P., Timson, D.J., Patil, S.V., Singhal, R.S., Antón, J., Dijksterhuis, J., Hocking, A.D., Lievens, B., Rangel, D.E.N., Voytek, M.A., Gunde-Cimerman, N., Oren, A., Timmis, K.N., McGenity, T.J., Hallsworth, J.E., 2015, Is there a common water-activity limit for the three domains of life: ISME Journal, 9, 1333-1351. https://doi.org/10.1038/ ismej.2014.219

Stoffregen, R.E., Alpers, C.N., Jambor, J.L., 2000, Alunite-jarosite crystallography, thermodynamics, and geochronology: Reviews in Mineralogy and Geochemistry, 40, 453-479. https://doi.org/10.2138/ rmg.2000.40.9

Sutjaritvorakul, T., Whalley, A.J.S., Roengsumran, S., Sihanonth, P., 2013, Solubilization and accumulation of insoluble zinc and lead compounds by fungi isolated from zinc mine: Journal of Pure and Applied Microbiology, 7, 1043-1046.

Taksavasu, T., Monecke, T., Reynolds, T.J., 2018, Textural characteristics of noncrystalline silica in sinters and quartz veins: Implications for the formation of bonanza veins in lowsulfidation epithermal deposits: Minerals, 8, 331. https://doi.org/10.3390/min8080331

Taylor, T.N., Krings, M., Taylor, E.L., 2015, Fossil fungi: Amsterdam, The Netherlands, Academic Press, 295 p.

Thompson, A.J.B., Hauff, P.L., Robitaille, A.J., 1999, Alteration mapping in exploration: application of short-wave infrared (SWIR) 
spectroscopy: Society of Economic Geologists Newsletter, 39, 16-27.

Thompson, A.J.B., Hauff, P.L., Robitaille, A.J., 2009, Alteration mapping in exploration: application of short-wave infrared (SWIR) spectroscopy, in Bedell, R., Crósta, A.P., Grunsky, E. (eds.), Remote Sensing and Spectral Geology: Reviews in Economic Geology, 16, 123-134. https://doi. org/10.5382/Rev. 16.03

Tornos, F., Solomon, M., Conde, C., Spiro, B.F., 2008, Formation of the Tharsis massive sulfide deposit, Iberian Pyrite Belt: Geological, lithogeochemical, and stable isotope evidence for deposition in a brine pool: Economic Geology, 103, 185-214. https:// dx.doi.org/10.2113/gsecongeo.103.1.185

Tritlla, J., Camprubí, A., Morales-Ramírez, J.M., Iriondo, A., Corona-Esquivel, R., GonzálezPartida, E., Levresse, G., Carrillo-Chávez, A., 2004, The Ixtacamaxtitlán kaolinite deposit and sinter (Puebla state, Mexico): a magmatichydrothermal system telescoped by a shallow paleoaquifer: Geofluids, 4, 329-340. https:// doi.org/10.1111/j.1468-8123.2004.00095.x

Turrini, A., Avio, L., Giovannetti, M., Agnolucci, M., 2018, Functional complementarity of arbuscular mycorrhizal fungi and associated microbiota: the challenge of translational research: Frontiers in Plant Science, 9, 1407. https://doi.org/10.3389/fpls.2018.01407

Valencia, V.A., Ruiz, J., Barra, F., Gehrels, G., Ducea, M., Titley, S.R., Ochoa-Landín, L., 2005, U-Pb zircon and Re-Os molybdenite geochronology from La Caridad porphyry copper deposit: Insightsfor the duration of magmatism and mineralization in the Nacozari District, Sonora, Mexico: Mineralium Deposita, 40, 175-191. http:// doi.org/10.1007/s00126-005-0480-1

Valencia, V.A., Eastoe, G., Ruiz, J., OchoaLandín, L., Gehrels, G., González-León, C., Barra, F., Espinoza, E., 2008, Hydrothermal evolution of the porphyry copper deposit at La Caridad, Sonora, Mexico, and the relationship with a neighboring highsulfidation epithermal deposit: Economic Geology, 103, 473-491. http://dx.doi. org/10.2113/gsecongeo.103.3.473

Van Dover, G.L., Ward, M.E., Scott, J.L., Underdown, J., Anderson, B., Gustafson, C., Whalen, M., Carnegie, R.B., 2007, A fungal epizooticinmusselsatadeep-seahydrothermal vent: Marine Ecology, 28, 54-62. https://doi. org/10.1111/j.1439-0485.2006.00121.x

Velador, J.M., Heizler, M.T., Campbell, A.R., 2010, Timing of magmatic activity and mineralization and evidence of a long-lived hydrothermal system in the Fresnillo silver district, Mexico: constraints from ${ }^{40} \mathrm{Ar} /{ }^{39} \mathrm{Ar}$ geochronology: Economic Geology, 105, 1335-1349. http://dx.doi.org/10.2113/ econgeo.105.7.1335

Viles, H.A., Gorbushina, A.A., 2003, Soiling and microbial colonization on urban roadside limestone: a three year study in Oxford, England: Building and Environment, 38, 1217-1224. https://doi.org/10.1016/ S0360-1323(03)00078-7

Wei, Z., Liang, X., Pendlowski, H., Hillier, S., Suntornvongsagul, K., Sihanonth, P., Gadd, G.M., 2013, Fungal biotransformation of zinc silicate and sulfide mineral ores: Environmental Microbiology, 15, 2173-2186. https://doi.org/10.1111/1462-2920.12089

Zamora-Vega, O., Richards, J.P., Spell, T., Dufrane, S.A., Williamson, J., 2018, Multiple mineralization events in the Zacatecas Ag-Pb$\mathrm{Zn}-\mathrm{Cu}-\mathrm{Au}$ district, and their relationship to the tectonomagmatic evolution of the Mesa Central, Mexico: Ore Geology Reviews, 102, 519-561. https://doi.org/10.1016/j. oregeorev.2018.09.010

Zhao, J., Liang, J., Long, X., Li, J., Xiang, Q., Zhang,J., Hao,J., 2018, Genesis and evolution of framboidal pyrite and its implications for the ore-forming process of Carlin-style gold deposits, southwestern China: Ore Geology Reviews, 102, 426-436. https://doi. org/10.1016/j.oregeorev.2018.09.022 


\section{APPENDIX}

Appendix 1 Calculations by using the PHREEQC on representative geothermal water of the Los Azufres field, Michoacán, after data from by González-Partida et al. (2005).

\begin{tabular}{|c|c|c|}
\hline $\mathrm{pH}$ & $\begin{array}{l}\text { Cumbres II } \\
\text { temp }\end{array}$ & si_SiOz(am) \\
\hline 2.81819 & 25 & 0.7338 \\
\hline 2.80281 & 26.016 & 0.726 \\
\hline 2.78763 & 27.033 & 0.7181 \\
\hline 2.77264 & 28.049 & 0.71 \\
\hline 2.75785 & 29.065 & 0.7018 \\
\hline 2.74324 & 30.081 & 0.6934 \\
\hline 2.72881 & 31.098 & 0.6848 \\
\hline 2.71456 & 32.114 & 0.6761 \\
\hline 2.70049 & 33.13 & 0.6673 \\
\hline 2.68659 & 34.146 & 0.6584 \\
\hline 2.67286 & 35.163 & 0.6493 \\
\hline 2.6593 & 36.179 & 0.6401 \\
\hline 2.6459 & 37.195 & 0.6309 \\
\hline 2.63266 & 38.211 & 0.6215 \\
\hline 2.61958 & 39.228 & 0.612 \\
\hline 2.60666 & 40.244 & 0.6025 \\
\hline 2.59389 & 41.26 & 0.5928 \\
\hline 2.58127 & 42.276 & 0.5831 \\
\hline 2.5688 & 43.293 & 0.5733 \\
\hline 2.55648 & 44.309 & 0.5635 \\
\hline 2.5443 & 45.325 & 0.5536 \\
\hline 2.53227 & 46.341 & 0.5437 \\
\hline 2.52039 & 47.358 & 0.5337 \\
\hline 2.50864 & 48.374 & 0.5236 \\
\hline 2.49705 & 49.39 & 0.5136 \\
\hline 2.48559 & 50.407 & 0.5035 \\
\hline 2.47427 & 51.423 & 0.4933 \\
\hline 2.4631 & 52.439 & 0.4831 \\
\hline 2.45207 & 53.455 & 0.4729 \\
\hline 2.44118 & 54.472 & 0.4627 \\
\hline 2.43043 & 55.488 & 0.4525 \\
\hline 2.41982 & 56.504 & 0.4422 \\
\hline 2.40936 & 57.52 & 0.4319 \\
\hline 2.39904 & 58.537 & 0.4217 \\
\hline 2.38886 & 59.553 & 0.4114 \\
\hline 2.37885 & 60.569 & 0.4011 \\
\hline 2.36901 & 61.585 & 0.3908 \\
\hline 2.35932 & 62.602 & 0.3805 \\
\hline 2.34977 & 63.618 & 0.3702 \\
\hline 2.34037 & 64.634 & 0.36 \\
\hline 2.33112 & 65.65 & 0.3497 \\
\hline 2.32202 & 66.667 & 0.3395 \\
\hline 2.31307 & 67.683 & 0.3292 \\
\hline 2.30427 & 68.699 & 0.319 \\
\hline 2.29563 & 69.715 & 0.3089 \\
\hline 2.28714 & 70.732 & 0.2987 \\
\hline 2.2788 & 71.748 & 0.2886 \\
\hline 2.27062 & 72.764 & 0.2785 \\
\hline 2.2626 & 73.78 & 0.2685 \\
\hline 2.25474 & 74.797 & 0.2585 \\
\hline 2.24704 & 75.813 & 0.2486 \\
\hline 2.2395 & 76.829 & 0.2387 \\
\hline 2.23213 & 77.846 & 0.2289 \\
\hline 2.22491 & 78.862 & 0.2192 \\
\hline 2.21787 & 79.878 & 0.2095 \\
\hline 2.21099 & 80.894 & 0.1999 \\
\hline 2.20427 & 81.911 & 0.1904 \\
\hline 2.19773 & 82.927 & 0.1809 \\
\hline 2.19136 & 83.943 & 0.1716 \\
\hline 2.18515 & 84.959 & 0.1623 \\
\hline 2.17912 & 85.976 & 0.1531 \\
\hline 2.17326 & 86.992 & 0.1441 \\
\hline
\end{tabular}

\begin{tabular}{|c|c|c|}
\hline pH & $\begin{array}{l}\text { Azufres I } \\
\text { temp }\end{array}$ & si_SiOz(am) \\
\hline 3.06114 & 25 & 0.5196 \\
\hline 3.0484 & 26.016 & 0.5134 \\
\hline 3.03594 & 27.033 & 0.507 \\
\hline 3.02376 & 28.049 & 0.5005 \\
\hline 3.01186 & 29.065 & 0.4939 \\
\hline 3.00023 & 30.081 & 0.4872 \\
\hline 2.98889 & 31.098 & 0.4803 \\
\hline 2.97781 & 32.114 & 0.4733 \\
\hline 2.96702 & 33.13 & 0.4663 \\
\hline 2.95649 & 34.146 & 0.4591 \\
\hline 2.94624 & 35.163 & 0.4518 \\
\hline 2.93627 & 36.179 & 0.4445 \\
\hline 2.92657 & 37.195 & 0.4371 \\
\hline 2.91715 & 38.211 & 0.4296 \\
\hline 2.90801 & 39.228 & 0.4221 \\
\hline 2.89915 & 40.244 & 0.4145 \\
\hline 2.89057 & 41.26 & 0.4069 \\
\hline 2.88227 & 42.276 & 0.3992 \\
\hline 2.87426 & 43.293 & 0.3915 \\
\hline 2.86654 & 44.309 & 0.3837 \\
\hline 2.85911 & 45.325 & 0.3759 \\
\hline 2.85198 & 46.341 & 0.3681 \\
\hline 2.84514 & 47.358 & 0.3602 \\
\hline 2.83861 & 48.374 & 0.3524 \\
\hline 2.83237 & 49.39 & 0.3445 \\
\hline 2.82645 & 50.407 & 0.3366 \\
\hline 2.82083 & 51.423 & 0.3287 \\
\hline 2.81552 & 52.439 & 0.3208 \\
\hline 2.81053 & 53.455 & 0.3129 \\
\hline 2.80585 & 54.472 & 0.305 \\
\hline 2.80148 & 55.488 & 0.2972 \\
\hline 2.79743 & 56.504 & 0.2893 \\
\hline 2.79369 & 57.52 & 0.2814 \\
\hline 2.79026 & 58.537 & 0.2736 \\
\hline 2.78714 & 59.553 & 0.2658 \\
\hline 2.78432 & 60.569 & 0.258 \\
\hline 2.7818 & 61.585 & 0.2502 \\
\hline 2.77957 & 62.602 & 0.2425 \\
\hline 2.77764 & 63.618 & 0.2348 \\
\hline 2.77598 & 64.634 & 0.2271 \\
\hline 2.77461 & 65.65 & 0.2194 \\
\hline 2.77351 & 66.667 & 0.2118 \\
\hline 2.77266 & 67.683 & 0.2042 \\
\hline 2.77207 & 68.699 & 0.1967 \\
\hline 2.77172 & 69.715 & 0.1892 \\
\hline 2.77161 & 70.732 & 0.1817 \\
\hline 2.77171 & 71.748 & 0.1743 \\
\hline 2.77203 & 72.764 & 0.1669 \\
\hline 2.77256 & 73.78 & 0.1596 \\
\hline 2.77327 & 74.797 & 0.1522 \\
\hline 2.77417 & 75.813 & 0.145 \\
\hline 2.77524 & 76.829 & 0.1378 \\
\hline 2.77647 & 77.846 & 0.1306 \\
\hline 2.77786 & 78.862 & 0.1234 \\
\hline 2.7794 & 79.878 & 0.1163 \\
\hline 2.78107 & 80.894 & 0.1093 \\
\hline 2.78287 & 81.911 & 0.1023 \\
\hline 2.78479 & 82.927 & 0.0953 \\
\hline 2.78683 & 83.943 & 0.0884 \\
\hline 2.78897 & 84.959 & 0.0815 \\
\hline 2.79122 & 85.976 & 0.0746 \\
\hline 2.79356 & 86.992 & 0.0678 \\
\hline
\end{tabular}

\begin{tabular}{|c|c|c|}
\hline $\mathrm{pH}$ & $\begin{array}{l}\text { Zimirao } \\
\text { temp }\end{array}$ & si_SiOz(am) \\
\hline 3.31246 & 25 & 0.193 \\
\hline 3.30262 & 26.016 & 0.1875 \\
\hline 3.29319 & 27.033 & 0.1819 \\
\hline 3.28416 & 28.049 & 0.1761 \\
\hline 3.27552 & 29.065 & 0.1702 \\
\hline 3.26728 & 30.081 & 0.164 \\
\hline 3.25943 & 31.098 & 0.1577 \\
\hline 3.25197 & 32.114 & 0.1513 \\
\hline 3.24489 & 33.13 & 0.1447 \\
\hline 3.23818 & 34.146 & 0.138 \\
\hline 3.23184 & 35.163 & 0.1312 \\
\hline 3.22587 & 36.179 & 0.1243 \\
\hline 3.22025 & 37.195 & 0.1172 \\
\hline 3.21499 & 38.211 & 0.11 \\
\hline 3.21006 & 39.228 & 0.1028 \\
\hline 3.20547 & 40.244 & 0.0954 \\
\hline 3.2012 & 41.26 & 0.088 \\
\hline 3.19724 & 42.276 & 0.0805 \\
\hline 3.19358 & 43.293 & 0.073 \\
\hline 3.19022 & 44.309 & 0.0653 \\
\hline 3.18715 & 45.325 & 0.0577 \\
\hline 3.18434 & 46.341 & 0.05 \\
\hline 3.18179 & 47.358 & 0.0422 \\
\hline 3.1795 & 48.374 & 0.0345 \\
\hline 3.17744 & 49.39 & 0.0267 \\
\hline 3.17561 & 50.407 & 0.0188 \\
\hline 3.174 & 51.423 & 0.011 \\
\hline 3.1726 & 52.439 & 0.0032 \\
\hline 3.17139 & 53.455 & -0.0047 \\
\hline 3.17037 & 54.472 & -0.0125 \\
\hline 3.16953 & 55.488 & -0.0203 \\
\hline 3.16886 & 56.504 & -0.0281 \\
\hline 3.16835 & 57.52 & -0.0359 \\
\hline 3.16798 & 58.537 & -0.0437 \\
\hline 3.16777 & 59.553 & -0.0515 \\
\hline 3.16765 & 60.569 & -0.0592 \\
\hline 3.16762 & 61.585 & -0.067 \\
\hline 3.16772 & 62.602 & -0.0747 \\
\hline 3.16793 & 63.618 & -0.0823 \\
\hline 3.16826 & 64.634 & -0.09 \\
\hline 3.16869 & 65.65 & -0.0976 \\
\hline 3.16922 & 66.667 & -0.1052 \\
\hline 3.16984 & 67.683 & -0.1127 \\
\hline 3.17056 & 68.699 & -0.1202 \\
\hline 3.17137 & 69.715 & -0.1276 \\
\hline 3.17227 & 70.732 & -0.135 \\
\hline 3.17325 & 71.748 & -0.1424 \\
\hline 3.1743 & 72.764 & -0.1497 \\
\hline 3.17544 & 73.78 & -0.157 \\
\hline 3.17666 & 74.797 & -0.1642 \\
\hline 3.17795 & 75.813 & -0.1714 \\
\hline 3.17931 & 76.829 & -0.1786 \\
\hline 3.18074 & 77.846 & -0.1857 \\
\hline 3.18225 & 78.862 & -0.1928 \\
\hline 3.18382 & 79.878 & -0.1998 \\
\hline 3.18546 & 80.894 & -0.2068 \\
\hline 3.18717 & 81.911 & -0.2138 \\
\hline 3.18895 & 82.927 & -0.2207 \\
\hline 3.19079 & 83.943 & -0.2276 \\
\hline 3.1927 & 84.959 & -0.2344 \\
\hline 3.19467 & 85.976 & -0.2412 \\
\hline 3.19671 & 86.992 & -0.248 \\
\hline
\end{tabular}

\begin{tabular}{|c|c|c|}
\hline \multicolumn{3}{|c|}{ Casa Lázaro Cárdenas } \\
\hline pH & temp & si_SiOz $(\mathrm{am})$ \\
\hline 3.62903 & 25 & -0.0154 \\
\hline 3.62572 & 26.016 & -0.0245 \\
\hline 3.62274 & 27.033 & -0.0337 \\
\hline 3.62006 & 28.049 & -0.043 \\
\hline 3.61767 & 29.065 & -0.0524 \\
\hline 3.61554 & 30.081 & -0.0619 \\
\hline 3.61366 & 31.098 & -0.0715 \\
\hline 3.61201 & 32.114 & -0.081 \\
\hline 3.61056 & 33.13 & -0.0907 \\
\hline 3.60931 & 34.146 & -0.1003 \\
\hline 3.60824 & 35.163 & -0.11 \\
\hline 3.60734 & 36.179 & -0.1196 \\
\hline 3.60659 & 37.195 & -0.1293 \\
\hline 3.60598 & 38.211 & -0.1389 \\
\hline 3.6055 & 39.228 & -0.1485 \\
\hline 3.60514 & 40.244 & -0.1581 \\
\hline 3.60489 & 41.26 & -0.1676 \\
\hline 3.60475 & 42.276 & -0.1771 \\
\hline 3.6047 & 43.293 & -0.1865 \\
\hline 3.60474 & 44.309 & -0.1959 \\
\hline 3.60487 & 45.325 & -0.2053 \\
\hline 3.60507 & 46.341 & -0.2145 \\
\hline 3.60534 & 47.358 & -0.2238 \\
\hline 3.60569 & 48.374 & -0.2329 \\
\hline 3.6061 & 49.39 & -0.242 \\
\hline 3.60658 & 50.407 & -0.251 \\
\hline 3.60711 & 51.423 & -0.26 \\
\hline 3.60771 & 52.439 & -0.2689 \\
\hline 3.60835 & 53.455 & -0.2777 \\
\hline 3.60906 & 54.472 & -0.2864 \\
\hline 3.60982 & 55.488 & -0.2951 \\
\hline 3.61062 & 56.504 & -0.3037 \\
\hline 3.61148 & 57.52 & -0.3123 \\
\hline 3.6124 & 58.537 & -0.3208 \\
\hline 3.61336 & 59.553 & -0.3292 \\
\hline 3.61433 & 60.569 & -0.3375 \\
\hline 3.61533 & 61.585 & -0.3458 \\
\hline 3.61638 & 62.602 & -0.354 \\
\hline 3.61748 & 63.618 & -0.3622 \\
\hline 3.61862 & 64.634 & -0.3703 \\
\hline 3.61982 & 65.65 & -0.3783 \\
\hline 3.62107 & 66.667 & -0.3863 \\
\hline 3.62237 & 67.683 & -0.3942 \\
\hline 3.62372 & 68.699 & -0.402 \\
\hline 3.62512 & 69.715 & -0.4098 \\
\hline 3.62658 & 70.732 & -0.4175 \\
\hline 3.62809 & 71.748 & -0.4252 \\
\hline 3.62965 & 72.764 & -0.4328 \\
\hline 3.63127 & 73.78 & -0.4404 \\
\hline 3.63294 & 74.797 & -0.4479 \\
\hline 3.63467 & 75.813 & -0.4554 \\
\hline 3.63646 & 76.829 & -0.4628 \\
\hline 3.6383 & 77.846 & -0.4701 \\
\hline 3.64021 & 78.862 & -0.4774 \\
\hline 3.64217 & 79.878 & -0.4847 \\
\hline 3.6442 & 80.894 & -0.4919 \\
\hline 3.64628 & 81.911 & -0.4991 \\
\hline 3.64843 & 82.927 & -0.5063 \\
\hline 3.65065 & 83.943 & -0.5134 \\
\hline 3.65292 & 84.959 & -0.5204 \\
\hline 3.65526 & 85.976 & -0.5274 \\
\hline 3.65767 & 86.992 & -0.5344 \\
\hline
\end{tabular}


Appendix 1. (Continuation) Calculations by using the PHREEQC on representative geothermal water of the Los Azufres field, Michoacán, after data from by González-Partida et al. (2005).

\begin{tabular}{|c|c|c|}
\hline $\mathrm{pH}$ & $\begin{array}{c}\text { Cumbres II } \\
\text { temp }\end{array}$ & $\mathrm{si} \mathrm{SiO}_{2}(\mathrm{am})$ \\
\hline 2.16757 & 88.008 & 0.1351 \\
\hline 2.16206 & 89.024 & 0.1262 \\
\hline 2.15672 & 90.041 & 0.1175 \\
\hline 2.15155 & 91.057 & 0.1088 \\
\hline 2.14656 & 92.073 & 0.1003 \\
\hline 2.14174 & 93.089 & 0.0919 \\
\hline 2.1371 & 94.106 & 0.0836 \\
\hline 2.13263 & 95.122 & 0.0755 \\
\hline 2.12833 & 96.138 & 0.0674 \\
\hline 2.1242 & 97.154 & 0.0595 \\
\hline 2.12025 & 98.171 & 0.0517 \\
\hline 2.11647 & 99.187 & 0.0441 \\
\hline 2.11286 & 100.203 & 0.0366 \\
\hline 2.10945 & 101.22 & 0.0292 \\
\hline 2.10621 & 102.236 & 0.0219 \\
\hline 2.10313 & 103.252 & 0.0148 \\
\hline 2.1002 & 104.268 & 0.0078 \\
\hline 2.09743 & 105.285 & 0.0009 \\
\hline 2.09482 & 106.301 & -0.0058 \\
\hline 2.09235 & 107.317 & -0.0124 \\
\hline 2.09002 & 108.333 & -0.0189 \\
\hline 2.08784 & 109.35 & -0.0253 \\
\hline 2.0858 & 110.366 & -0.0315 \\
\hline 2.08388 & 111.382 & -0.0377 \\
\hline 2.0821 & 112.398 & -0.0437 \\
\hline 2.08044 & 113.415 & -0.0496 \\
\hline 2.0789 & 114.431 & -0.0554 \\
\hline 2.07747 & 115.447 & -0.0611 \\
\hline 2.07616 & 116.463 & -0.0666 \\
\hline 2.07495 & 117.48 & -0.0721 \\
\hline 2.07384 & 118.496 & -0.0775 \\
\hline 2.07282 & 119.512 & -0.0828 \\
\hline 2.0719 & 120.528 & -0.088 \\
\hline 2.07106 & 121.545 & -0.0931 \\
\hline 2.07031 & 122.561 & -0.0981 \\
\hline 2.06963 & 123.577 & -0.1031 \\
\hline 2.06902 & 124.593 & -0.1079 \\
\hline 2.06848 & 125.61 & -0.1127 \\
\hline 2.06801 & 126.626 & -0.1174 \\
\hline 2.06759 & 127.642 & -0.1221 \\
\hline 2.06723 & 128.659 & -0.1267 \\
\hline 2.06693 & 129.675 & -0.1312 \\
\hline 2.06667 & 130.691 & -0.1357 \\
\hline 2.06645 & 131.707 & -0.14 \\
\hline 2.06628 & 132.724 & -0.1444 \\
\hline 2.06615 & 133.74 & -0.1487 \\
\hline 2.06605 & 134.756 & -0.1529 \\
\hline 2.06598 & 135.772 & -0.1571 \\
\hline 2.06595 & 136.789 & -0.1612 \\
\hline 2.06594 & 137.805 & -0.1653 \\
\hline 2.06596 & 138.821 & -0.1694 \\
\hline 2.066 & 139.837 & -0.1734 \\
\hline 2.06606 & 140.854 & -0.1774 \\
\hline 2.06614 & 141.87 & -0.1813 \\
\hline 2.06623 & 142.886 & -0.1852 \\
\hline 2.06634 & 143.902 & -0.1891 \\
\hline 2.06647 & 144.919 & -0.1929 \\
\hline 2.0666 & 145.935 & -0.1967 \\
\hline 2.06675 & 146.951 & -0.2005 \\
\hline 2.06691 & 147.967 & -0.2042 \\
\hline 2.06708 & 148.984 & -0.2079 \\
\hline & & \\
\hline
\end{tabular}

\begin{tabular}{|c|c|c|}
\hline pH & $\begin{array}{l}\text { Azufres I } \\
\text { temp }\end{array}$ & si_siOz $(\mathrm{am})$ \\
\hline 2.79599 & 88.008 & 0.061 \\
\hline 2.79851 & 89.024 & 0.0542 \\
\hline 2.80111 & 90.041 & 0.0475 \\
\hline 2.80379 & 91.057 & 0.0408 \\
\hline 2.80654 & 92.073 & 0.0342 \\
\hline 2.80935 & 93.089 & 0.0276 \\
\hline 2.81224 & 94.106 & 0.021 \\
\hline 2.81519 & 95.122 & 0.0145 \\
\hline 2.81819 & 96.138 & 0.0079 \\
\hline 2.82126 & 97.154 & 0.0015 \\
\hline 2.82438 & 98.171 & -0.005 \\
\hline 2.82755 & 99.187 & -0.0114 \\
\hline 2.83076 & 100.203 & -0.0178 \\
\hline 2.83399 & 101.22 & -0.0242 \\
\hline 2.83726 & 102.236 & -0.0305 \\
\hline 2.84058 & 103.252 & -0.0368 \\
\hline 2.84394 & 104.268 & -0.0431 \\
\hline 2.84734 & 105.285 & -0.0494 \\
\hline 2.85078 & 106.301 & -0.0556 \\
\hline 2.85427 & 107.317 & -0.0618 \\
\hline 2.85779 & 108.333 & -0.068 \\
\hline 2.86135 & 109.35 & -0.0742 \\
\hline 2.86495 & 110.366 & -0.0803 \\
\hline 2.86859 & 111.382 & -0.0864 \\
\hline 2.87226 & 112.398 & -0.0925 \\
\hline 2.87596 & 113.415 & -0.0986 \\
\hline 2.8797 & 114.431 & -0.1046 \\
\hline 2.88347 & 115.447 & -0.1106 \\
\hline 2.88727 & 116.463 & -0.1166 \\
\hline 2.8911 & 117.48 & -0.1226 \\
\hline 2.89497 & 118.496 & -0.1286 \\
\hline 2.89886 & 119.512 & -0.1345 \\
\hline 2.90279 & 120.528 & -0.1404 \\
\hline 2.90674 & 121.545 & -0.1463 \\
\hline 2.91072 & 122.561 & -0.1522 \\
\hline 2.91473 & 123.577 & -0.158 \\
\hline 2.91877 & 124.593 & -0.1639 \\
\hline 2.92283 & 125.61 & -0.1697 \\
\hline 2.92692 & 126.626 & -0.1755 \\
\hline 2.93104 & 127.642 & -0.1812 \\
\hline 2.93518 & 128.659 & -0.187 \\
\hline 2.93935 & 129.675 & -0.1927 \\
\hline 2.94354 & 130.691 & -0.1985 \\
\hline 2.94775 & 131.707 & -0.2042 \\
\hline 2.95199 & 132.724 & -0.2098 \\
\hline 2.95625 & 133.74 & -0.2155 \\
\hline 2.96053 & 134.756 & -0.2211 \\
\hline 2.96483 & 135.772 & -0.2268 \\
\hline 2.96915 & 136.789 & -0.2324 \\
\hline 2.97349 & 137.805 & -0.238 \\
\hline 2.97786 & 138.821 & -0.2435 \\
\hline 2.98224 & 139.837 & -0.2491 \\
\hline 2.98664 & 140.854 & -0.2546 \\
\hline 2.99106 & 141.87 & -0.2601 \\
\hline 2.9955 & 142.886 & -0.2656 \\
\hline 2.99995 & 143.902 & -0.2711 \\
\hline 3.00442 & 144.919 & -0.2766 \\
\hline 3.00891 & 145.935 & -0.282 \\
\hline 3.01341 & 146.951 & -0.2874 \\
\hline 3.01792 & 147.967 & -0.2928 \\
\hline 3.02245 & 148.984 & \\
\hline
\end{tabular}

\begin{tabular}{|c|c|c|}
\hline pH & $\begin{array}{l}\text { Zimirao } \\
\text { temp }\end{array}$ & si_siOz(am) \\
\hline 3.19881 & 88.008 & -0.2547 \\
\hline 3.20098 & 89.024 & -0.2614 \\
\hline 3.20321 & 90.041 & -0.2681 \\
\hline 3.2055 & 91.057 & -0.2747 \\
\hline 3.20786 & 92.073 & -0.2813 \\
\hline 3.21029 & 93.089 & -0.2879 \\
\hline 3.21278 & 94.106 & -0.2944 \\
\hline 3.21533 & 95.122 & -0.301 \\
\hline 3.21795 & 96.138 & -0.3074 \\
\hline 3.22063 & 97.154 & -0.3139 \\
\hline 3.22338 & 98.171 & -0.3203 \\
\hline 3.22619 & 99.187 & -0.3267 \\
\hline 3.22905 & 100.203 & -0.3331 \\
\hline 3.23189 & 101.22 & -0.3395 \\
\hline 3.23479 & 102.236 & -0.3459 \\
\hline 3.23776 & 103.252 & -0.3522 \\
\hline 3.2408 & 104.268 & -0.3586 \\
\hline 3.2439 & 105.285 & -0.3649 \\
\hline 3.24707 & 106.301 & -0.3711 \\
\hline 3.2503 & 107.317 & -0.3774 \\
\hline 3.25361 & 108.333 & -0.3836 \\
\hline 3.25698 & 109.35 & -0.3899 \\
\hline 3.26042 & 110.366 & -0.3961 \\
\hline 3.26392 & 111.382 & -0.4023 \\
\hline 3.2675 & 112.398 & -0.4085 \\
\hline 3.27114 & 113.415 & -0.4146 \\
\hline 3.27485 & 114.431 & -0.4208 \\
\hline 3.27864 & 115.447 & -0.4269 \\
\hline 3.28249 & 116.463 & -0.433 \\
\hline 3.28641 & 117.48 & -0.4391 \\
\hline 3.2904 & 118.496 & -0.4452 \\
\hline 3.29446 & 119.512 & -0.4513 \\
\hline 3.29859 & 120.528 & -0.4574 \\
\hline 3.30279 & 121.545 & -0.4635 \\
\hline 3.30706 & 122.561 & -0.4695 \\
\hline 3.3114 & 123.577 & -0.4756 \\
\hline 3.31581 & 124.593 & -0.4816 \\
\hline 3.3203 & 125.61 & -0.4876 \\
\hline 3.32485 & 126.626 & -0.4937 \\
\hline 3.32947 & 127.642 & -0.4997 \\
\hline 3.33417 & 128.659 & -0.5057 \\
\hline 3.33893 & 129.675 & -0.5117 \\
\hline 3.34377 & 130.691 & -0.5177 \\
\hline 3.34868 & 131.707 & -0.5237 \\
\hline 3.35366 & 132.724 & -0.5297 \\
\hline 3.35871 & 133.74 & -0.5356 \\
\hline 3.36383 & 134.756 & -0.5416 \\
\hline 3.36902 & 135.772 & -0.5476 \\
\hline 3.37428 & 136.789 & -0.5536 \\
\hline 3.37961 & 137.805 & -0.5595 \\
\hline 3.38502 & 138.821 & -0.5655 \\
\hline 3.39049 & 139.837 & -0.5714 \\
\hline 3.39603 & 140.854 & -0.5774 \\
\hline 3.40165 & 141.87 & -0.5833 \\
\hline 3.40733 & 142.886 & -0.5892 \\
\hline 3.41309 & 143.902 & -0.5952 \\
\hline 3.41891 & 144.919 & -0.6011 \\
\hline 3.4248 & 145.935 & -0.607 \\
\hline 3.43077 & 146.951 & -0.613 \\
\hline 3.4368 & 147.967 & -0.6189 \\
\hline 3.4429 & 148.984 & -0.6248 \\
\hline 3.44907 & 150 & -0.6307 \\
\hline
\end{tabular}

\begin{tabular}{|c|c|c|}
\hline \multicolumn{3}{|c|}{ Casa Lázaro Cárdenas } \\
\hline pH & temp & si_SiOz $(\mathrm{am})$ \\
\hline 3.66015 & 88.008 & -0.5414 \\
\hline 3.66269 & 89.024 & -0.5483 \\
\hline 3.6653 & 90.041 & -0.5551 \\
\hline 3.66798 & 91.057 & -0.562 \\
\hline 3.67073 & 92.073 & -0.5688 \\
\hline 3.67355 & 93.089 & -0.5756 \\
\hline 3.67645 & 94.106 & -0.5824 \\
\hline 3.67941 & 95.122 & -0.5891 \\
\hline 3.68245 & 96.138 & -0.5958 \\
\hline 3.68557 & 97.154 & -0.6025 \\
\hline 3.68876 & 98.171 & -0.6091 \\
\hline 3.69202 & 99.187 & -0.6158 \\
\hline 3.69535 & 100.203 & -0.6224 \\
\hline 3.69869 & 101.22 & -0.629 \\
\hline 3.70211 & 102.236 & -0.6356 \\
\hline 3.70561 & 103.252 & -0.6421 \\
\hline 3.70919 & 104.268 & -0.6487 \\
\hline 3.71285 & 105.285 & -0.6552 \\
\hline 3.71659 & 106.301 & -0.6617 \\
\hline 3.72041 & 107.317 & -0.6682 \\
\hline 3.72432 & 108.333 & -0.6747 \\
\hline 3.7283 & 109.35 & -0.6812 \\
\hline 3.73237 & 110.366 & -0.6877 \\
\hline 3.73652 & 111.382 & -0.6941 \\
\hline 3.74076 & 112.398 & -0.7006 \\
\hline 3.74508 & 113.415 & -0.707 \\
\hline 3.74948 & 114.431 & -0.7134 \\
\hline 3.75398 & 115.447 & -0.7198 \\
\hline 3.75855 & 116.463 & -0.7262 \\
\hline 3.76322 & 117.48 & -0.7326 \\
\hline 3.76797 & 118.496 & -0.739 \\
\hline 3.7728 & 119.512 & -0.7454 \\
\hline 3.77773 & 120.528 & -0.7518 \\
\hline 3.78274 & 121.545 & -0.7582 \\
\hline 3.78784 & 122.561 & -0.7646 \\
\hline 3.79303 & 123.577 & -0.7709 \\
\hline 3.79831 & 124.593 & -0.7773 \\
\hline 3.80367 & 125.61 & -0.7837 \\
\hline 3.80913 & 126.626 & -0.79 \\
\hline 3.81467 & 127.642 & -0.7964 \\
\hline 3.8203 & 128.659 & -0.8028 \\
\hline 3.82603 & 129.675 & -0.8091 \\
\hline 3.83184 & 130.691 & -0.8155 \\
\hline 3.83774 & 131.707 & -0.8219 \\
\hline 3.84373 & 132.724 & -0.8282 \\
\hline 3.84981 & 133.74 & -0.8346 \\
\hline 3.85598 & 134.756 & -0.841 \\
\hline 3.86224 & 135.772 & -0.8473 \\
\hline 3.86859 & 136.789 & -0.8537 \\
\hline 3.87503 & 137.805 & -0.8601 \\
\hline 3.88155 & 138.821 & -0.8664 \\
\hline 3.88817 & 139.837 & -0.8728 \\
\hline 3.89487 & 140.854 & -0.8792 \\
\hline 3.90167 & 141.87 & -0.8856 \\
\hline 3.90855 & 142.886 & -0.892 \\
\hline 3.91552 & 143.902 & -0.8984 \\
\hline 3.92258 & 144.919 & -0.9047 \\
\hline 3.92973 & 145.935 & -0.9111 \\
\hline 3.93696 & 146.951 & -0.9175 \\
\hline 3.94428 & 147.967 & -0.9239 \\
\hline 3.95169 & 148.984 & -0.9303 \\
\hline & & \\
\hline
\end{tabular}


Appendix 1. (Continuation) Calculations by using the PHREEQC on representative geothermal water of the Los Azufres field, Michoacán, after data from by González-Partida et al. (2005).

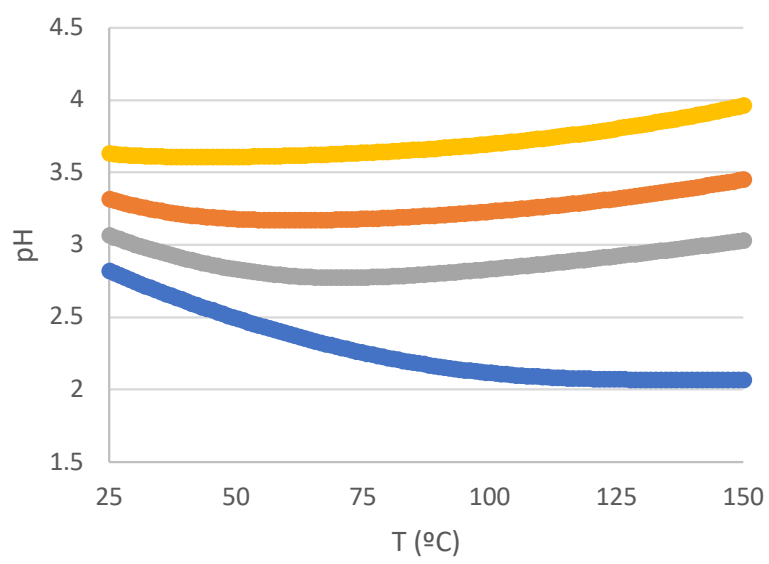

- Cumbres II

- Azufres I

-Zimirao

- Casa Lázaro Cárdenas

Los Azufres

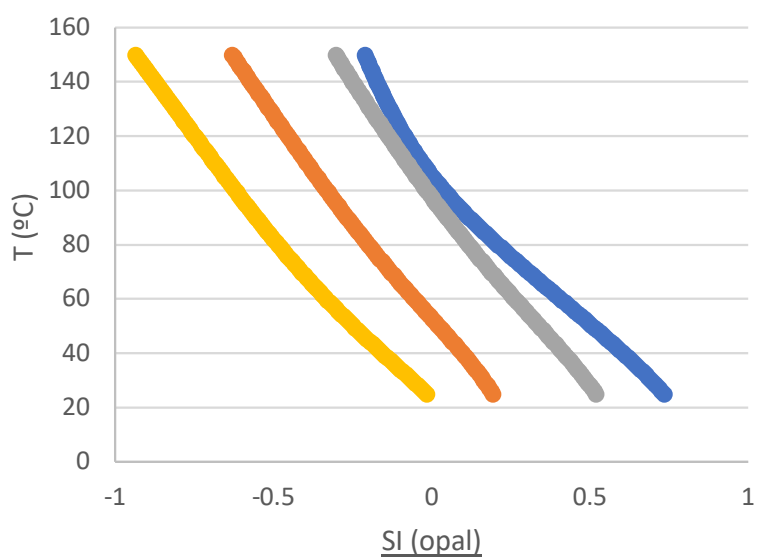

- Cumbres II

Azufres I

- Zimirao

- Casa Lázaro Cárdenas

Los Azufres

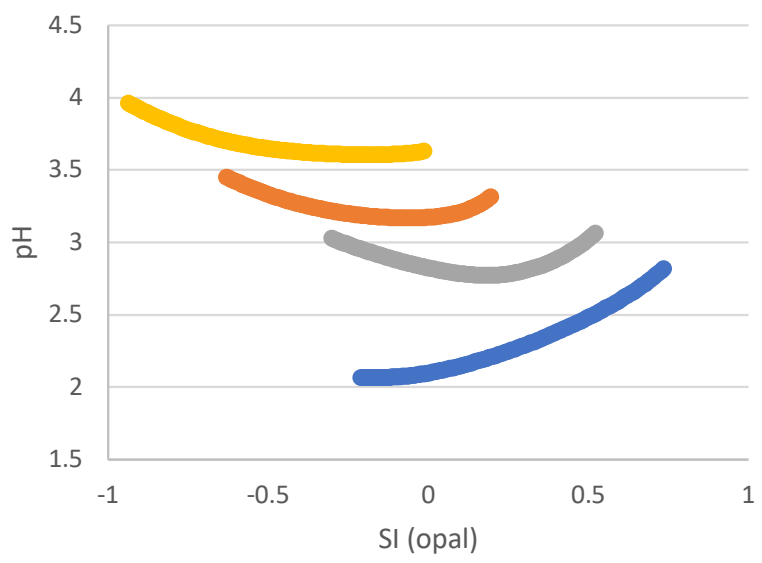

- Cumbres II

Azufres I

- Zimirao

- Casa Lázaro Cárdenas 